\title{
Debris entrainment and transfer in polythermal valley glaciers
}

\author{
Michael J. Hambrey, ${ }^{1}$ Matthew R. Bennett, ${ }^{2}$ Julian A. Dowdeswell, ${ }^{3}$ \\ Neil F. Glasser, ${ }^{4}$ David Huddart ${ }^{5}$ \\ 'Centre for Glaciology, Institute of Geography and Earth Sciences, University of Wales, Aberystwyth, Geredigion Sr23.3DB, Wales \\ ${ }^{2}$ School of Earth Sciences, University of Greenwich, Medway Towns Campus, Pembroke, Chatham Maritime, Kent ME4 4AW, England \\ ${ }^{3}$ Bristol Glaciology Centre, School of Geographical Sciences, University of Bristol, Bristol BS8 1SS, England \\ ${ }^{4}$ School of Biological and Earth Sciences, Liverpool fohn Moores University, Byrom Street, Liverpool L3 $3 A F$, England \\ ${ }^{5}$ School of Education and Community Studies, Liverpool John Moores University, I. M. Marsh Campus, Liverpool L.37 6EN, England
}

\begin{abstract}
Modes of debris entrainment and subsequent transfer in seven "normal" and five surge-type glaciers in Svalbard $\left(76-79^{\circ} \mathrm{N}\right)$ are outlined in the context of the structural evolution of a glacier as the ice deforms during flow. Three main modes of entrainment and transfer are inferred from structural and sedimentological observations: (i) The incorporation of angular rockfall material within the stratified sequence of snow/firn/superimposed ice. This debris takes an englacial path through the glacier, becoming folded. At the margins and at the boundaries of flow units the stratified ice including debris is strongly folded, so that near the snout the debris emerges at the surface on the hinges and limbs of the folds, producing medial moraines which merge towards the snout. The resulting lines of debris are transmitted to the proglacial area in the form of regular trains of angular debris. (ii) Incorporation of debris of both supraglacial and basal character within longitudinal foliation. This is particularly evident at the surface of the glacier at the margins or at flow unit boundaries. It can be sometimes demonstrated that foliation is a product of strong folding, since it usually has an axial planar relationship with folded stratification. Foliation-parallel debris thus represents a more advanced stage of deformation than in (i). Although the presence of basal debris is problematic, it is proposed that this material is tightly folded ice derived from the bed in the manner of disharmonic folding. The readily deformed subglacial sediment or bedrock surface represents the plane of décollement. (iii) Thrusting, whereby debris-rich basal ice (including regelation ice) and subglacial sediments are uplifted into an englacial position, sometimes emerging at the ice surface. This material is much more variable in character than that derived from rockfalls, and reflects the substrate lithologies; diamicton with striated clasts and sandy gravels are the most common facies represented. Thrusting is a dynamic process, and in polythermal glaciers is probably linked mainly to the transition from sliding to frozen bed conditions. It is not therefore a solely ice-marginal or proglacial process.
\end{abstract}

\section{INTRODUCTION}

Modern Arctic glaciers provide excellent opportunities for the study of debris in transport because of the combination of relatively clean ice surfaces, steep-sided margins and, occasionally, tidewater cliff sections. It is thus possible to decipher how debris is transported in basal, englacial and supraglacial positions, particularly if the relationships between ice structures (foliation, folding and thrusting) and debris are resolved. This paper explores these relationships for a variety of surge-type and non-surge-type glaciers, and offers new models for the transfer of debris in such glaciers. Cold or polythermal glaciers differ from temperate glaciers in generally having a much greater load of basally derived debris (Boulton, 1970; Dowdeswell, 1986; Knight, 1997). However, it has also been suggested that the true contrast is greater between surge-type glaciers (greater basal debris content) and non-surge-type glaciers (Clapperton, 1975), irrespective of their thermal regime. Contrasting views have emerged concerning the development of englacial debris-rich layers that appear to rise towards the glacier surface from the bed, as summarised by Boulton (1970, p. 720; Knight, 1997). Some authors (Weertman, 1961; Hooke, 1973) have favoured passive movement of subglacially derived debris as the ice flowlines turn upwards towards the frontal margin, while others (Swinzow, 1962; Hambrey and Müller, 1978) have suggested that thrusting and shearing are the processes which allow debris-rich basal ice, or subglacial debris, to rise to the surface along discrete surfaces or narrow zones of rapidly deforming ice. From studies in Svalbard, Norway, Boulton (1970) made a convincing case for the incorporation of debris by thrusting, by identifying folds with truncated lower limbs. On Axel Heiberg Island, Canadian Arctic Archipelago, Hambrey and Müller (1978) linked the development of debris-bearing thrust zones to pre-existing structures, especially crevasse traces that had become rotated from a vertical to a gentle, up-glacier-dipping attitude near the snout of White Glacier. In closely monitored Trapridge Glacier, Yukon Territory, Canada, Clarke and Blake (1991) linked thrusting and recumbent folding with the transition from warm to cold ice 
at the bed. More recently, the association of debris-bearing thrusts with the movement of a surge front through a glacier has been described from Bakaninbreen in Svalbard (Hambrey and others, 1996; Murray and others 1997). Thrusting has also been documented in temperate glaciers, but only in surge-type glaciers does there appear to be significant incorporation of debris (e.g. Sharp and others 1994). In a review of debris entrainment processes, Alley and others (1997) conclude that incorporation of debris by thrusting and folding are valid mechanisms.

In contrast to studies of the basal debris load of Arctic glaciers, those concerned with supraglacial transport are few. However, observations on many glaciers by the authors suggest that debris derived from supraglacial sources carried on cold or polythermal glaciers is much less than on temperate glaciers. In all cases, supraglacial debris transport is generally concentrated in lateral or medial moraines. Other authors investigating medial moraine development in temperate glaciers have attempted to identify sources of debris in relation to the firn line and to flow-unit boundaries, and the effect these have on their morphology (e.g. Eyles and Rogerson, 1977; Small and others, 1979; Vere and Benn, 1989). However, the various models that have been proposed by these authors for temperate valley glaciers, which are based on convergence of discrete flow units, do not explain certain types of medial moraine in Svalbard.

This paper, therefore, examines the processes whereby ice deformation influences the incorporation and redistribution of debris within polythermal glaciers in Svalbard (Fig. 1). The sedimentary facies associated with the different deformational processes are also characterised. The principal relationships between debris and structure that are explored are:

(i) rockfall debris associated with sedimentary stratification;

(ii) basally derived debris associated with longitudinal foliation; and

(iii) basally derived sediment forming arcuate debris layers, thought to be associated with thrusting.

Mechanisms related to the formation of the basal debris layer are also important (see reviews by Hubbard and Sharp, 1989; Souchez and Lorrain, 1991; Knight, 1997), but are considered only superficially in this paper, as few suitable sites were available for study at the Svalbard glaciers. These mechanisms include regelation, flow through a vein system, bulk freezing-on, shearing and folding (Knight, 1997). The basal debris layer is generally thin in temperate glaciers, but can become thicker by folding, shearing and thrusting (Sharp and others, 1994; Hart, 1995). As a framework for the following discussion, the known and inferred sources of debris and modes of incorporation are summarised in Figure 2.

Understanding the processes of debris entrainment and modification during flow is critical to explaining landform assemblages in the proglacial areas of Arctic glaciers. This understanding takes on added importance because many Pleistocene landforms in Europe and North America are more similar to those observed at modern Arctic glacier margins than to those at alpine glaciers (Boulton, 1967, 1972; Sollid and Sørbel, 1988; Hambrey and Huddart, 1995; Bennett and others, 1996b, in press; Huddart and Hambrey, 1996; Hambrey and others, 1997). Hence, investigations of this nature are also needed in order to examine the climatic implications of Quaternary glacial landform assemblages.

\section{MODERN GLACIERS IN SVALBARD}

Svalbard (approximately $77-80^{\circ} \mathrm{N}$ ) (Fig. lc) is an archipelago affected by a maritime-Arctic climate, and is $60 \%$ glacierized (Hagen and others, 1993). From observations of the thermal regime of a small number of glaciers, it is believed that extensive areas of temperate ice occur beneath the accumulation areas of the thicker glaciers, whereas the ice margins and snout areas are frozen to the bed (Hagen and Sætrang, 1991; Odegård and others, 1992; Björnsson and others, 1996; Jania and others, 1996; Nuttall and others, 1997). In such "polythermal" glaciers, the transition from sliding to freezing conditions at the bed has been used to explain why thrusting is an important process in the incorporation of debris into glacier ice (Clarke and Blake, 1991; Hambrey and others, 1996), and leads to the development of proglacial thrust-moraine complexes of hummocky character (Hambrey and Huddart, 1995; Bennett and others, 1996a, b; Huddart and Hambrey, 1996; Hambrey and others, 1997).

Many glaciers in Svalbard are of the surge type. Over 80 have been observed to surge (Dowdeswell and others, 1991; Hagen and others, 1993). Studies of looped moraines and other surface features diagnostic of former surges suggest that about $35 \%$ of Svalbard ice masses may be of surge type (Hamilton and Dowdeswell, 1996).

\section{GLACIERS INVESTIGATED}

Twelve glaciers, of both surge and non-surge type, were investigated along the west coast of Spitsbergen, Svalbard, between Kongsfjorden in the north and Hornsund in the south (Fig. 1). Surge-type glaciers are recognised in their quiescent state by their looped medial moraine patterns, crevasse-free nature and well-developed supraglacial stream networks with broad, open or sealed potholes (Meier and Post, 1969; Post and LaChapelle, 1971). The glaciers investigated range from small- to medium-sized valley glaciers several km long terminating on land, to large complex tidewater systems tens of $\mathrm{km}$ long. In all cases, multiple accumulation basins feed ice into relatively narrow tongues, while ice structures, particularly foliation, can be used to delineate the composite flow units. Those glaciers inferred to be non-surge type from surface structural and morphological evidence were Midre Lovénbreen, Austre Lovénbreen, Uvêrsbreen, Edithbreen and Steenbreen (Fig. 1). However, it has been claimed that the first two are surge-type on the basis of the steep frontal cliffs observed at the beginning of the century (Liestøl, 1988), a feature that is common to all advancing polythermal and cold glaciers. Furthermore, the complex of "push moraines" at Uvêrsbreen has been inferred by Croot (1988) to indicate surge-type behaviour, a criterion which we believe to be unreliable (Hambrey and Huddart, 1995; Huddart and Hambrey, 1996). Surge-type glaciers studied were Kongsvegen, Pedersenbreen, Bakaninbreen, Hessbreen and Finsterwalderbreen (Fig. 1). All these glaciers except the second (Bennett and others, 1996b) have a known surge history, whilst Bakaninbreen was approaching the end of a sustained surge when the work was undertaken (Dowdeswell and others, 1991). Additional observations were made on Austre Broggerbreen, which is 

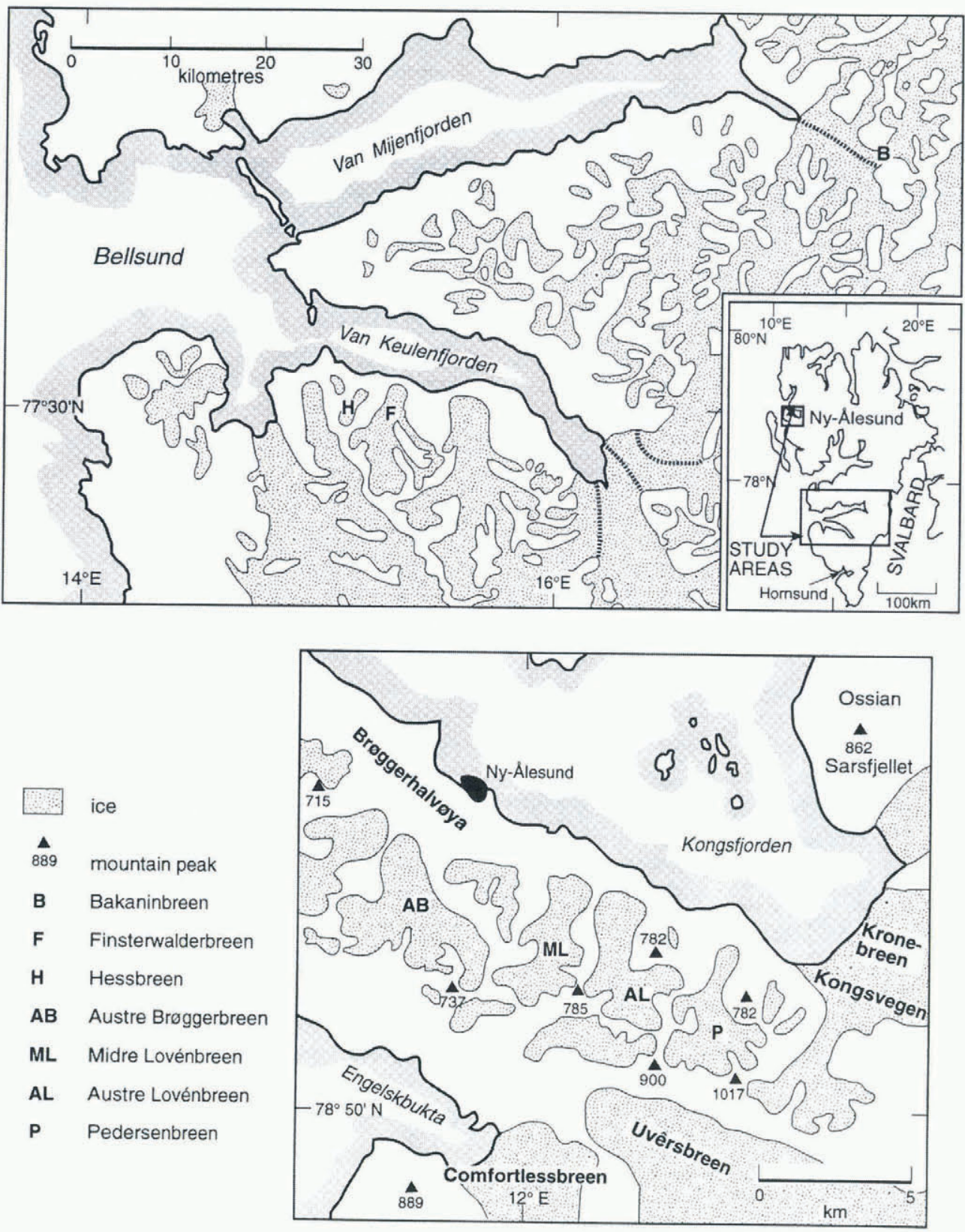

Fig. 1. Location map of glaciers investigated in Svalbard. (a) Van Mijenfjorden and Van Keulenfjorden area; (b) Ny-Alesund (Kongsfjorden) area; (c) key map of Svalbard.

a thin glacier, almost completely frozen to its bed (Liestøl, 1988), and Hansbreen in Hornsund, a tidewater glacier whose dynamic character is uncertain. Table 1 lists the principal characteristics of these glaciers. All of them are currently receding.

\section{METHODS}

Ice structures, inferred to be longitudinal foliation and thrusts, in the snout areas of Midre Lovénbreen and Finsterwalderbreen were mapped from 1:15000 (1991) and 1:30000 (1995) vertical aerial photographs of the Norsk Polarinstitutt, Oslo, respectively, while their three-dimensional orientations were recorded on the ground. The dominant structures measured were longitudinal foliation and transverse arcuate layers (with debris in places), interpreted as thrusts. The orientations of smaller-scale structures, such as the axes of minor folds, not visible in the photographs, were also measured.

In order to characterise debris sources, the size, sorting, fabric and shape characteristics of debris associated with thrusts, folds and foliation were recorded and compared with material of known origin, such as scree, glaciofluvial sediment or basal till. Sorting was estimated visually. Fabric was recorded in two dimensions for material related to fold structures and plotted on rose diagrams. Data from thrusts are three-dimensional and are plotted on Schmidt equalarea stereographic projections; both point-plots and contour-plots are given, and eigenvalues are calculated to illustrate the strength of the fabric. In each case 50 clasts were measured. To characterise shape, Krumbein roundness values were obtained from a visual roundness chart, while the lengths of the long $(a)$, intermediate $(b)$ and short $(c)$ axes, were also recorded. Again, each dataset contained a population of 50 clasts. Clast-surface features such as facets and striations were also documented. The data were analyzed using the approach advocated by Benn and Ballantyne (1994) in which the RA index (percentage of angular and very angular clasts) is plotted against the $\mathrm{C}_{40}$ index (percentage of clasts with $c / a$ ratios of 0.4 ), or as a covariant plot (Bennett and others, 1997). 


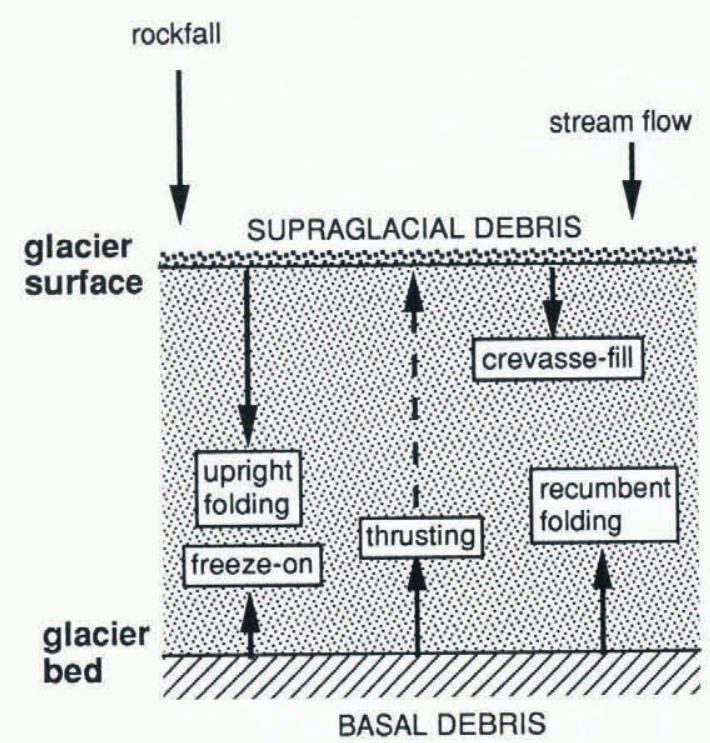

Fig. 2. Schematic representation of principal sources and modes of incorporation of debris in Svalbard glaciers.

\section{ICE STRUCTURES IN SVALBARD GLACIERS}

All the glaciers examined appear to have up to five recognisable types of planar structure, which have developed sequentially in the same manner. These are labelled $\mathrm{S}_{0}-\mathrm{S}_{4}$, in order of formation in a particular "parcel" of ice. The first structure is primary stratification, inherited from snowfalls in the accumulation area $\left(\mathbf{S}_{0}\right)$. This is sometimes intersected by a set or sets of crevasse traces $\left(\mathrm{S}_{1}\right)$, developed in the upper basin of the glacier, although this structure has not been delineated in all cases owing to the limited observations. The next structure is longitudinal foliation $\left(\mathrm{S}_{2}\right)$, which occurs in all glaciers, and is evident down-glacier of the topographic constriction that is invariably present at the mouth of the upper basin. Multiple sets of crevasse traces $\left(\mathrm{S}_{3}\right)$ intersect the foliation at various angles, and are best represented in the glacier tongue. Finally, arcuate fractures, sometimes with debris, and interpreted as thrusts $\left(\mathrm{S}_{4}\right)$ occur towards the snout of the glacier, although, if they are not associated with debris, they are difficult to distinguish from $\mathrm{S}_{3}$. The relative importance of particular structures may depend on whether the glacier is surge-type or not, but the pattern is not yet clear, as a larger sample size is needed to assess this. The overall structural sequence has already been described for Hessbreen (Hambrey and Dowdeswell, 1997) and Kongsvegen (Glasser and others, 1998), while thrusts have been described specifically from the surge front and downglacier surface of Bakaninbreen (Hambrey and others, 1996). In view of the general similarities with the other glaciers, the emphasis here is placed on those structures that are associated with debris transport.

\section{Debris associated with primary stratification}

\section{Character of stratification}

Primary stratification is inherited from the accumulation of snow and superimposed ice in the accumulation area. It is observed most clearly in aerial photographs of glacier ablation zones, where it commonly forms a diffuse, wavy, broadly transverse pattern extending across the ice surface. On the glacier surface, stratification is defined by alternations of coarse bubbly ice and coarse clear ice, and in some areas by sheets of angular gravel. Dip is variable but generally low, reflecting open-style folding. In certain longitudinal zones the folding is much tighter with steep limbs and fold axes normally dipping gently up-glacier. These more intensely folded zones coincide with flow-unit boundaries.

\section{Fold styles as indicated by debris distribution}

Some stratified horizons are associated with concentrations of mainly angular gravel, including numerous clasts of boulder size. The style and intensity of folding gives rise to the characteristic debris-distribution patterns observed at the glacier surface. These relationships are illustrated in two representative glaciers, Midre Lovénbreen, which shows no evidence of being surge-type (Fig. 3a), and the surge-type Finsterwalderbreen (Fig. 3b). Strongly folded ice typically has a "similar" style (i.e. attenuated limbs and thickened hinges). If the fold axes plunge gently up-glacier,

Table 1. Type, location and length of glaciers investigated in Svalbard. Data on latitude, longitude, length and dates of last surge are from Hagen and others (1993)

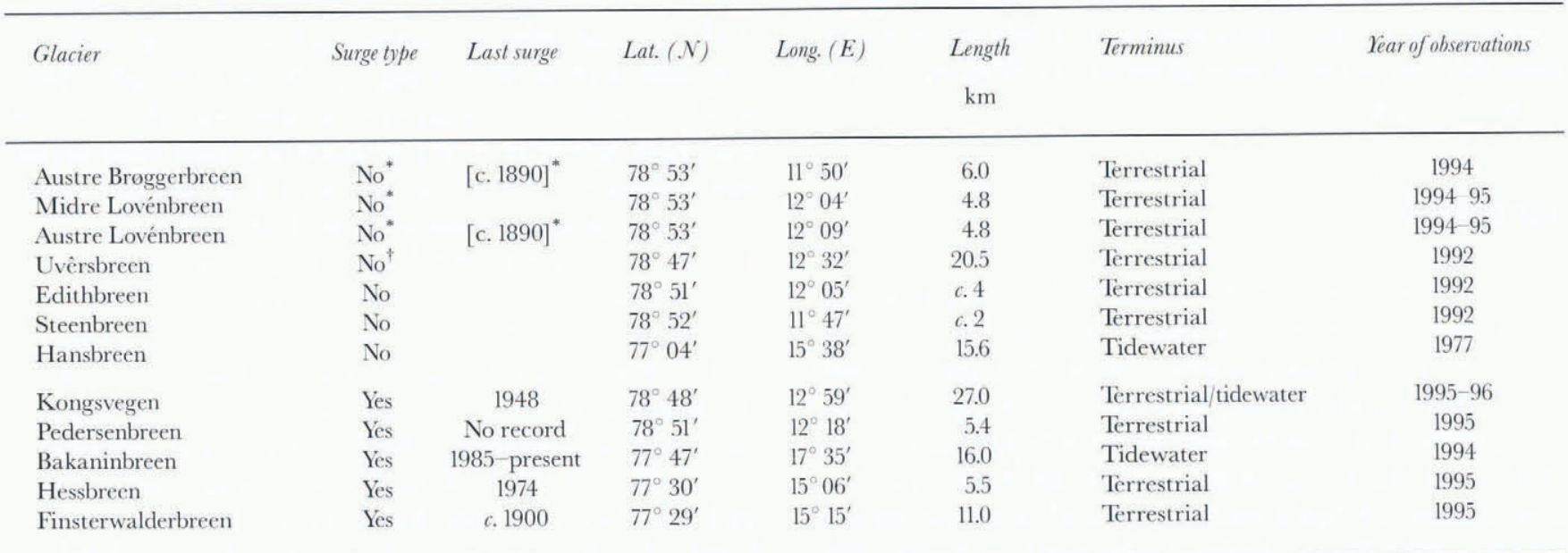

* These glaciers are noted as having surged in Liestol (1988) and Hagen and others (1993); in the absence of the usual structural indications of surge-type behaviour, in this paper the inferred surges are regarded as normal Neoglacial advances with steep frontal cliffs.

† Uvêrsbreen was inferred by Croot (1988) to be of surge type on the basis of a well-developed "push-moraine" complex; it has been argued that this moraine complex was not produced by a surge, while other moraines of this type are not necessarily restricted to surge-type glaciers (Hambrey and Huddart, 1995). 

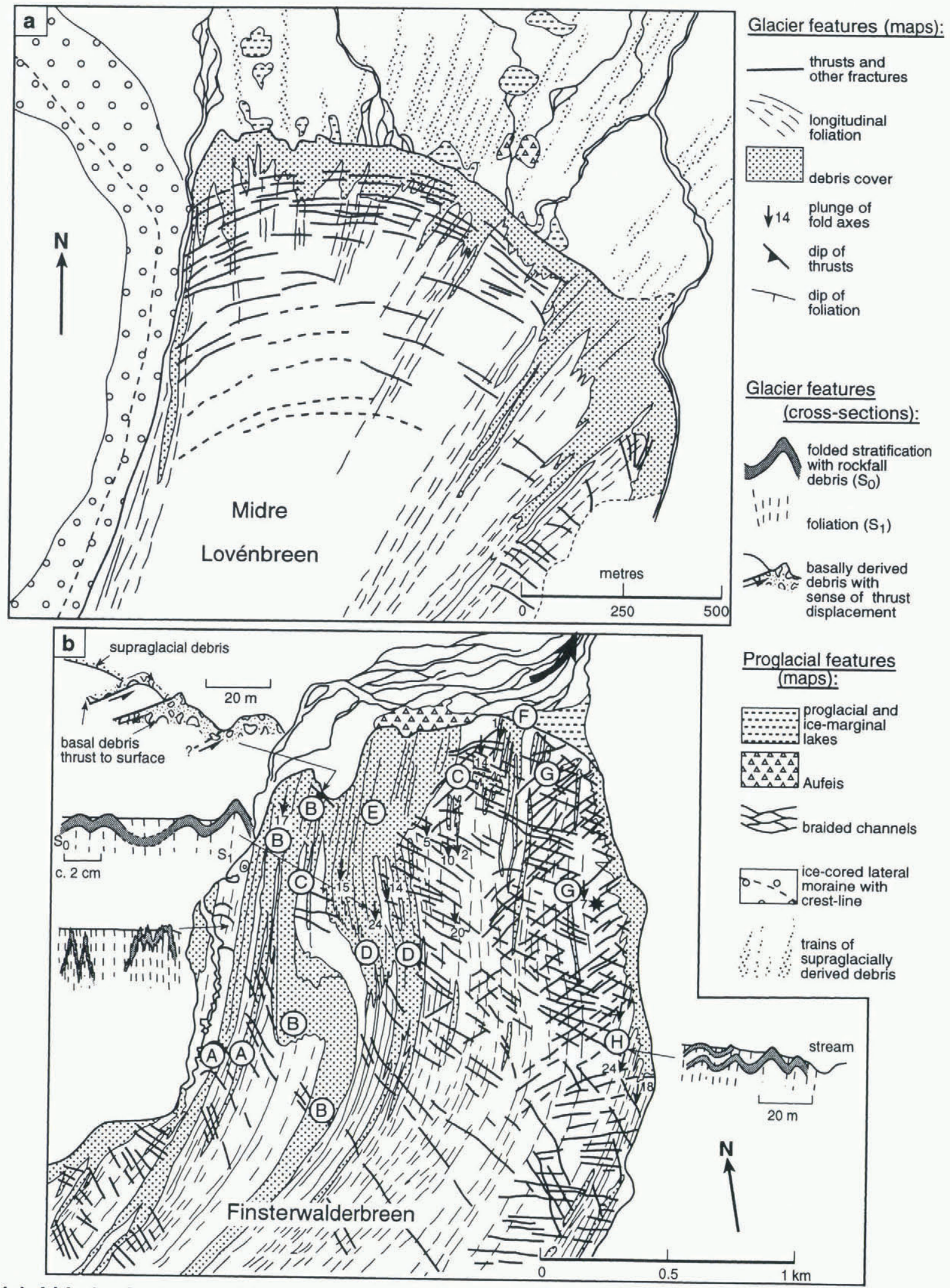

(c) Lithological assemblages, Finsterwalderbreen:
(A) Grey chert + dark grey limestone
(B) Marble + phyllite + quartzite + cherty limestone-limestone breccia
(C) Phyllite
(D) Sandstone + red mudstone + conglomerate + limestone + phyllite + marble
(E) Phyllite + minor marble + limestone
(F) Quartzite + minor phyllite + limestone
(G) Marble
(H) Sandstone (maroon, green, grey, black)

Fig. 3. Maps of ice struclures at the termini of two Svalbard valley glaciers, derived from aerial photographs. (a) Midre Lovénbreen, inferred to be of the non-surge type, based on 1991 photographs. Trains of supraglacially derived debris, linked to medial moraines, extend across the proglacial area. (b) Finsterwalderbreen, a surge-type glacier in its quiescent state, based on 1995 photographs; cross-sections of parts of the glacier depict structural relationships and styles of folding; cross-section top left is parallel to ice flow, the others are transverse to flow. (c) Lithological assemblages, indicated by encircled letters. 
as is normally the case, a debris layer emerges at one or more point sources, and becomes progressively more broadly spread across the ice surface as more of the folded layer is exposed by ablation (Fig. 4a). The normal up-glacier plunge may be altered to a transverse attitude where looped moraines have developed in surge-type glaciers (Fig. 4b). Differential melting often enables the detailed form of the folds to be established with confidence (Fig. 3b).

Less common is chevron-style folding, where the layers demonstrate a near-uniform thickness across the sharply defined fold hinges (Fig. 5). Chevron folds involving debris ablate differentially to give particularly clear fold crestlines, which in detail show undulatory trends, and occasionally anastomose over distances of several metres (Fig. 4c). In ice with more open folds, the debris emerges beneath the ice surface in a uniform spread (Fig. 4d). Where measured, as on Finsterwalderbreen, fold axes appear to have a consistent orientation, regardless of their position and intensity of folding (Fig. 3b). In all cases the debris-rich layers are parallel to stratification and have sharp boundaries, indicating that they were probably incorporated into the stratification in a series of instantaneous rockfall events.

Debris-rich folded layers are analogous to folds in deformed rocks. From measurements at three sites, two-dimensional clast fabrics along the crests of folded debris layers demonstrate that the long axes have a preferred orientation parallel to the fold axes (Fig. 6a and b). In kinematic terms, this alignment is probably equivalent to stretching lineation in deformed rocks, and indicates that the maximum extending cumulative strain axis is parallel to the fold axis, whereas the maximum compression is normal to the axial plane. Further data of this type are needed to verify whether this is a universal relationship.

\section{Surface expression of folding}

As tightly folded debris layers emerge, they develop into linear ridges that widen and merge towards the snout. They may be described as medial moraines, but their origin is quite different from the usual models that are presented for these landforms (e.g. Eyles and Rogerson, 1978; Small and others, 1979). The ridges typically extend from several metres to a few hundred metres across the ice surface (Fig. 3). If the fold axis undulates relative to the ice surface, the ridge may be discontinuous as the debris layer plunges in and out of the surface (Fig. 3b).

Individual folded debris layers commonly consist of a single lithology, but an adjacent layer may be of a different lithology. Thus, traverses across a series of fold-defined parallel ridges near the snouts of the several glaciers yielded multiple successions, with repetition of some beds, as one finds when mapping a strongly folded geological succession. For example, a traverse across a series of ridges of varying lithology, from west to east across the snout of Midre Lovénbreen, showed a variety of unilithology moraines, comprising schist, phyllite, amphibolitic gneiss, augen gneiss, and psammite and phyllite together. This pattern reflects different point sources in the headwalls prior to folding within the ice.

On Finsterwalderbreen, a similar pattern emerges, although because of the much more varied geology in the source areas, most ridges comprise distinct lithological associations, rather than single lithologies. This pattern is indicated by the encircled letters in Figure $3 \mathrm{~b}$. The inference that may be drawn from these observations is that single lithologies, or lithological associations, often represent the same stratum. Their repeated occurrence on transverse profiles is due to the intersection of the folded debris layers with the glacier surface in various positions, so defining the gross structure of the glacier.

\section{Shape and sorting characteristics of debris}

In order to assist in the definition of debris-transport paths through the glaciers, shape analysis was performed on the entrained debris (cf. Boulton, 1978; Dowdeswell, 1986; Hambrey, 1994; Bennett and Glasser, 1996). In the case of material associated with stratification, the seven samples collected showed strong clustering within the very angular and angular classes (group 2 data in Fig. 7a). This shape distribution compares closely with material collected from scree (group 1 data in Fig. 7a). Clear discrimination from other facies is achieved with an RA/C 40 plot (Benn and Ballantyne, 1994; Bennett and others, 1997), and highlights especially the high degree of angularity of the material.

The degree of sorting of material carried by ice is indicative of the extent of comminution during flow. Although, no systematic grain-size analyses were made on these samples, the bulk of the material is in the boulder, cobble and pebble categories, with minor amounts of coarse sand. Thus, samples associated with stratification are, in general, moderately well sorted, indicating little comminution or reduction in grain-size due to frost action.

\section{Character of stratification in surge-type glaciers}

Surge-type glaciers are characterised by looped moraines (e.g. Meier and Post, 1969; Post and LaChapelle, 1971; Clarke, 1991; Lawson, 1996), but the structural significance of these closed loops has rarely been studied. The structure of closed loops was investigated on Finsterwalderbreen, Hessbreen and Pedersenbreen, each of which shares common characteristics. Rather than debris-rich zones of valley-side material dipping vertically or steeply into the ice parallel to foliation as one might expect, the debris layers comprise material of angular character, representing the surface expression of folds with axes plunging gently upglacier (Fig. 8a and b). The apices of the loops show a broad spread of debris, whereas the limbs, aligned parallel to the valley sides, show more constrained debris layers of moderate dip. Some loops (e.g. those on Hessbreen) show a series of such layers.

Related to loops, but indicating less deformation, are Zor S-shaped folds, as on Finsterwalderbreen (Fig. 3b) and Pedersenbreen. These folded moraines reflect differential flow after surge ice from a tributary has entered the main body of the glacier and settled down into steady-state flow. The axial-plane foliation associated with these folds pervades the entire loop structure, and maintains an attitude parallel to the valley sides throughout. In some cases, loops may be rotated into a transverse attitude, especially if ice has to flow around a sharp curve, as on Bakaninbreen. This may result in the axes of folds and the associated foliation developing a transverse orientation.

Curious features associated with recently surged ice (as on Bakaninbreen) are fields of ice mounds a few metres high and of the order of 5-10 $\mathrm{m}$ in diameter. Internal stratification in these mounds sometimes shows a dome-like structure broadly parallel to the external morphology. In a few cases rings of debris may be associated with such mounds, when 
the core of the mound may have melted away through differential ablation, giving rise to a crater-like structure (Fig. 4e). Although they are difficult to explain, one possibility is that these structures are the product first of transverse com- pression which produces folded stratification with axes parallel to flow (as in steady-state flow), followed by longitudinal compression as the surge front passed through. In a geological sense, such ice-mound fields represent a
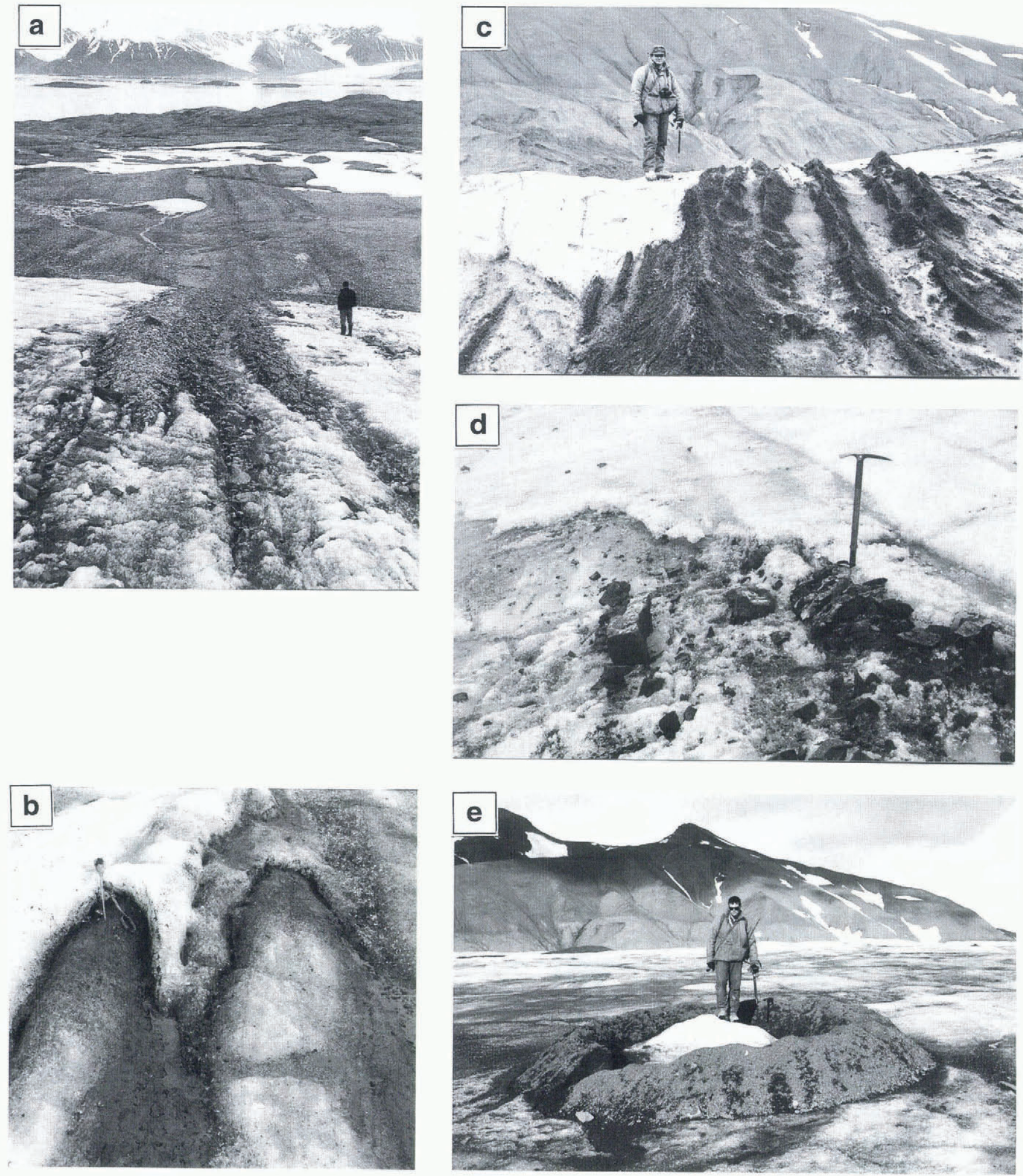

Fig. 4. Relationship between stratification and supraglacial debris (glaciers illustrated shown in Figure 1). (a) Emergence of supraglacial debris up-glacier of the snout of Austre Lovénbreen; the long linear ridges, parallel to longitudinal foliation, represent the hinge lines of tight folds. (b) "Similar-style" folding (open and attenuated limbs, thickened hinges) of muddy supraglacial debris (derived from shale) in Bakaninbreen; the ice-axe shaft is placed along the fold axis; note also the weak vertical foliation which forms an axial planar relationship to the folds. (c) Ridges of supraglacially derived mudstone forming sets of chevron-type folds, transverse to flow, close to the surge front of Bakaninbreen; the ridge crests of debris are undulating and represent fold axes. (d) Supraglacially derived englacial debris forming an open, low-amplitude fold in the middle of a flow unit in Hessbreen; the ice-axe is at the boundary between a debris-rich stratum (foreground) and a debris-free stratum (background). (e) Englacial debris from a supraglacial source emerging to form a cone-like structure in Bakaninbreen; this structure is inferred to be a refolded fold. 


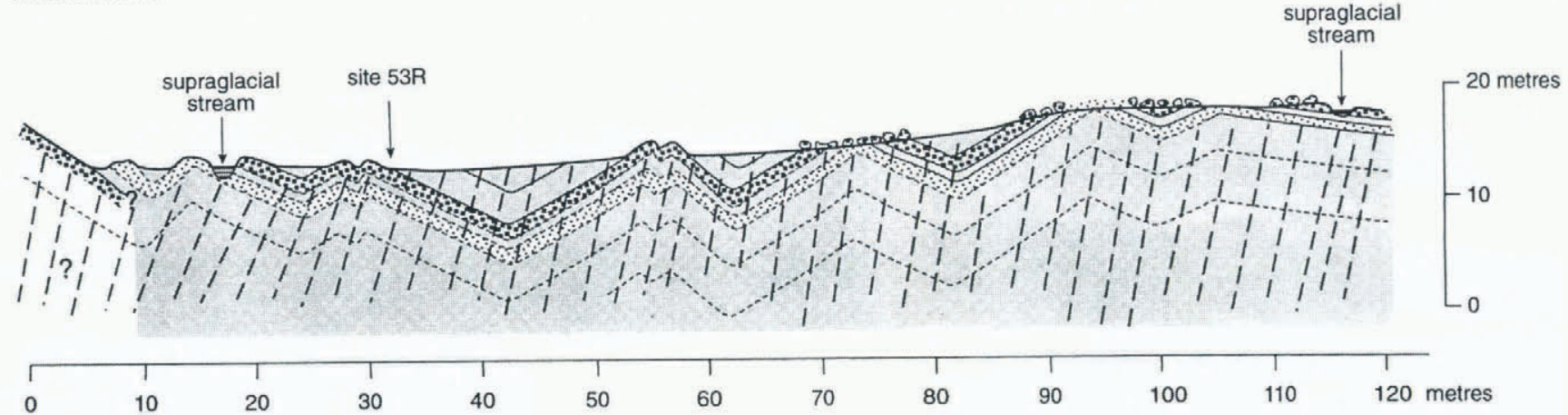

$\square$ clean ice

Fig. 5. Cross-section illustrating the structure of a single flow unit, measured by tape and compass/clinometer in the middle of the surge front of Bakaninbreen, August 1994. Note the chevron nature of the folding, defined by angular debris of two main sedimentary facies: angular gravel and gravelly sand. Solid lines between facies boundaries indicate observed structure (as in gullies and stream channels); dashed lines indicate inferred structure. The longitudinal foliation, in axial planar relationship to the folds, is inclined consistently at $75-85^{\circ}$ to the north.

dome-and-basin structure, the product of two phases of folding with stresses operating in two near-perpendicular orientations. Such features, however, would not survive many years of ablation following a surge, and the well-defined domes of debris eventually become irregular smears on the ice surface.

\section{Debris associated with foliation}

Longitudinal foliation is a ubiquitous structure of all the glaciers studied. In contrast to what happens in many alpine glaciers which have icefalls (e.g. Allen and others, 1960;
Hambrey and Milnes, 1977), longitudinal foliation is not overprinted by arcuate foliation, so generally can be traced from the equilibrium line almost to the snout. Following Allen and others' (1960) definition of ice types, longitudinal foliation is typically composed of coarse bubbly, coarse clear and occasionally fine-grained ice (Fig. 9). It is generally most obvious near the ice margins and at flow-unit boundaries where the foliae are closely spaced, and may disappear completely in the middle of broad flow units, although this depends on: (i) the extent to which the ice is constricted as it leaves the upper basin; and (ii) whether large amounts of ice

\section{SUPRAGLACIAL DEBRIS}

a

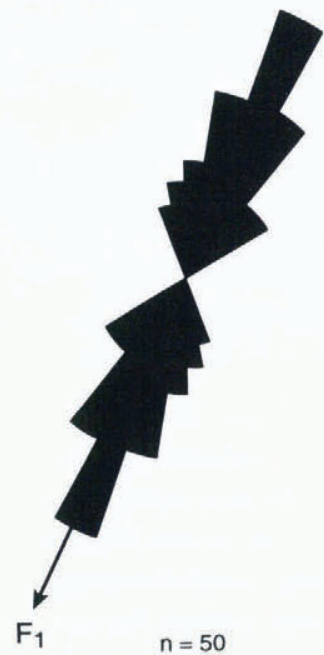

b

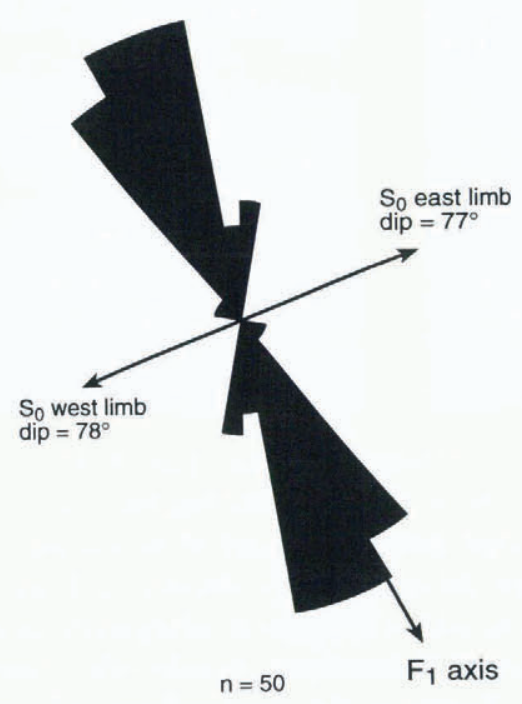

FOLIATION-PARALLEL SUBGLACIALLY DERIVED DEBRIS

c

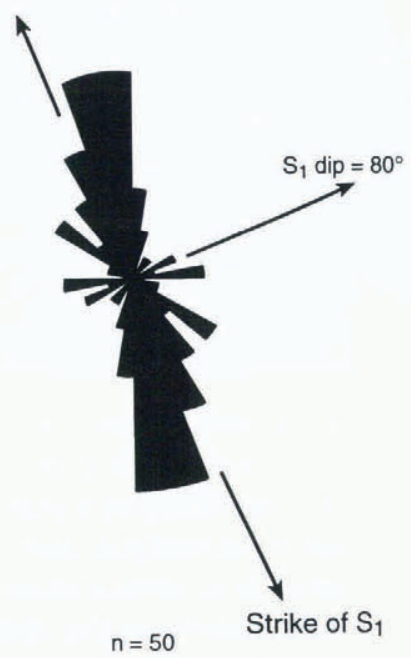

Fig. 6. Two-dimensional clast-orientation data in supraglacially and basally derived debris in zones parallel to longitudinal foliation, Finsterwalderbreen and Kongsvegen. The preferred orientation is exactly parallel to longitudinal foliation, which in turn is approximately parallel to inferred flow direction. 


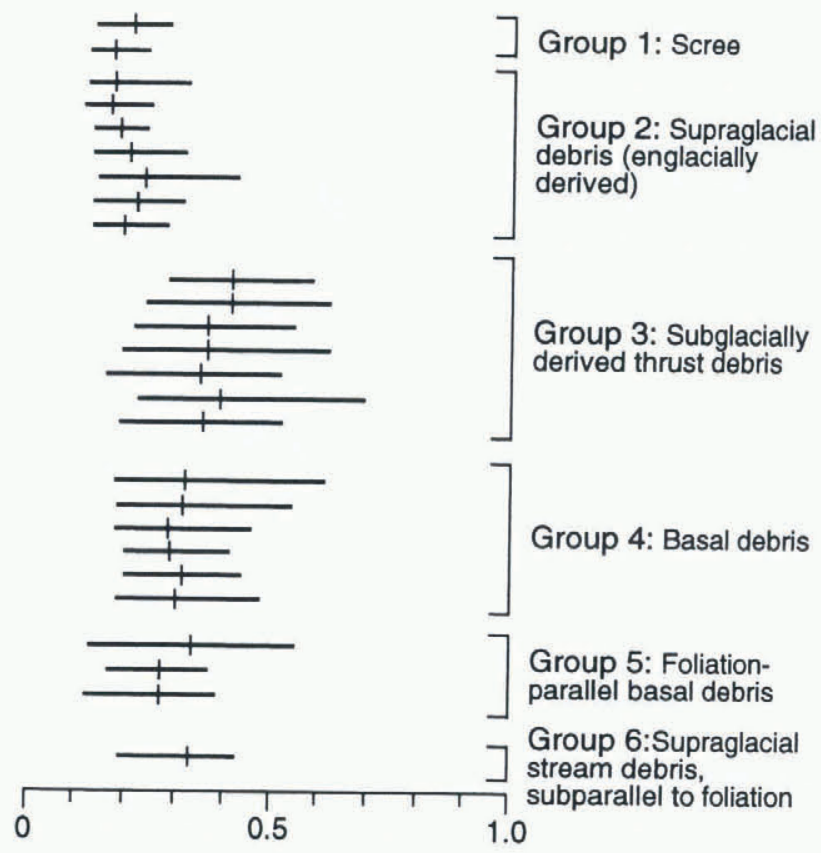

Krumbein roundness b

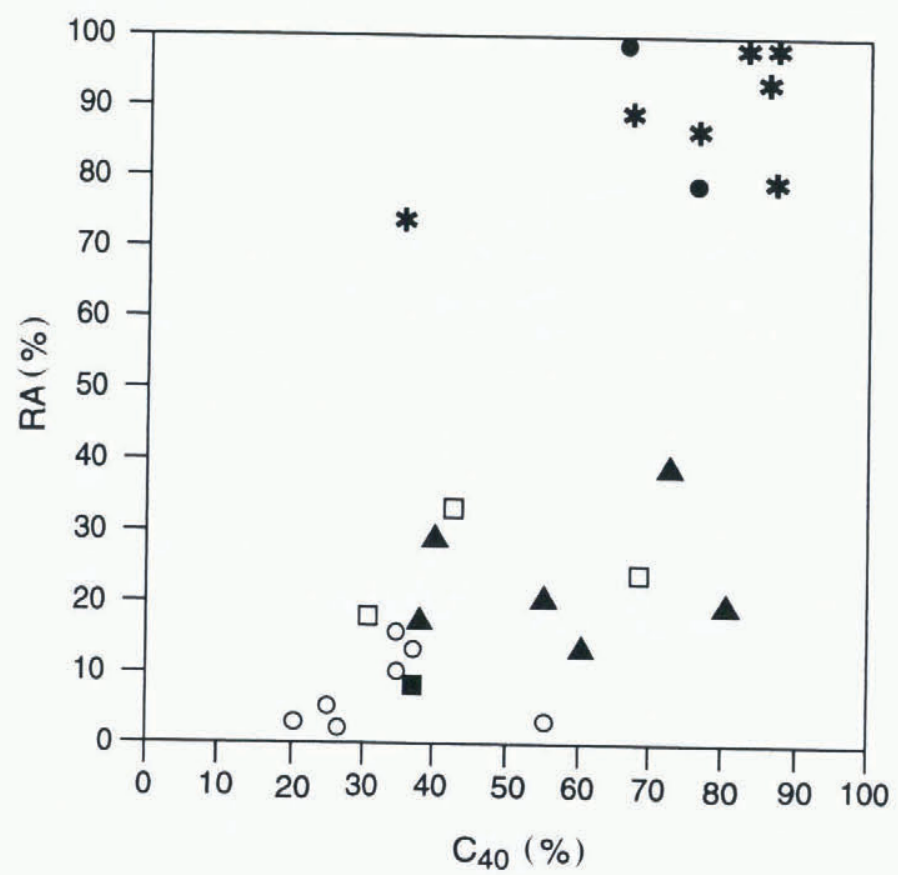

KEY
- Group 1: Scree

* Group 2 : Supraglacial debris (englacially derived)

○ Group 3: Subglacially derived thrust debris

- Group 4: Basal debris

Group 5 : Foliation-parallel basal debris

- Group 6: Supraglacial stream debris, subparallel to foliation

\begin{abstract}
Fig. 7. Analyses from all the glaciers investigated except Hansbreen of shape data of pebble/cobble-sized material associated with different structures and linked to a supraglacial or subglacial origin. (a) Plot of mean and range of Krumbein roundness, based on 50 measurements per sample. (b) Plot of the RA index (percentage of angular and very angular clasts) against the $C_{40}$ index (percentage of clasts with a c/a ratio of < 0.4), following Benn and Ballantyne (1994) and Bennett and others (1997).
\end{abstract}

are transferred through the system without sufficient internal deformation, such as during a surge. Contrasting examples are non-surge-type White Glacier which has strong longitudinal foliation throughout most of its width (Hambrey and Müller, 1978), and surge-type Hessbreen which has only localised foliation near the margins and at flow-unit boundaries (Hambrey and Dowdeswell, 1997).

The orientation of foliation remains mainly within $15^{\circ}$ of the vertical, except near the margins where the dip often decreases rapidly to approach that of the bed. Normally, this relationship is the result of "transposition" of older layering, and involves isoclinal folding with attenuation of limbs (Hambrey, 1977; Hooke and Hudleston, 1978). However, in the Svalbard glaciers, the foliation cross-cuts the more open folded layers in a similar manner to slaty cleavage in rocks folded in a more open style. Where the foliation is strongest, however, the stratification may be completely overprinted.

Debris is associated with foliation in a variety of ways: (i) disseminated unevenly through the ice in low concentrations (Fig. 10a); (ii) concentrated as thin (sub-centimetre) zones in fine foliated (heavily sheared) ice; (iii) as concentrated layers up to several $\mathrm{cm}$ wide in which the proportion of debris may exceed $50 \%$ by volume (Fig. 10b); (iv) as discontinuous pods up to several $\mathrm{cm}$ wide, slightly cross-cutting but trending sub-parallel to the foliation; (v) both disseminated and concentrated in layers in folded foliation sequences, where the foliation may be derived from stratification, but not demonstrably so (Fig. 10c). Of these, the discontinuous pods were only observed on Kongsvegen, and may be related to deformation of a gravel-filled channel that once trended parallel to the foliation Bennett and others, 1996a). Similar features have been described recently from glaciers in Iceland and New Zealand (Kirkbride and Spedding, 1996).

Unlike debris layers parallel to stratification, foliationparallel debris comprises a wide range of shapes, with a predominance of subangular and subrounded clasts (group 5 data, Fig. 7), which resemble debris that was extracted from basal ice (group 4 data). In addition, depending on the lithology, many of the clasts show faceted and striated sur- 

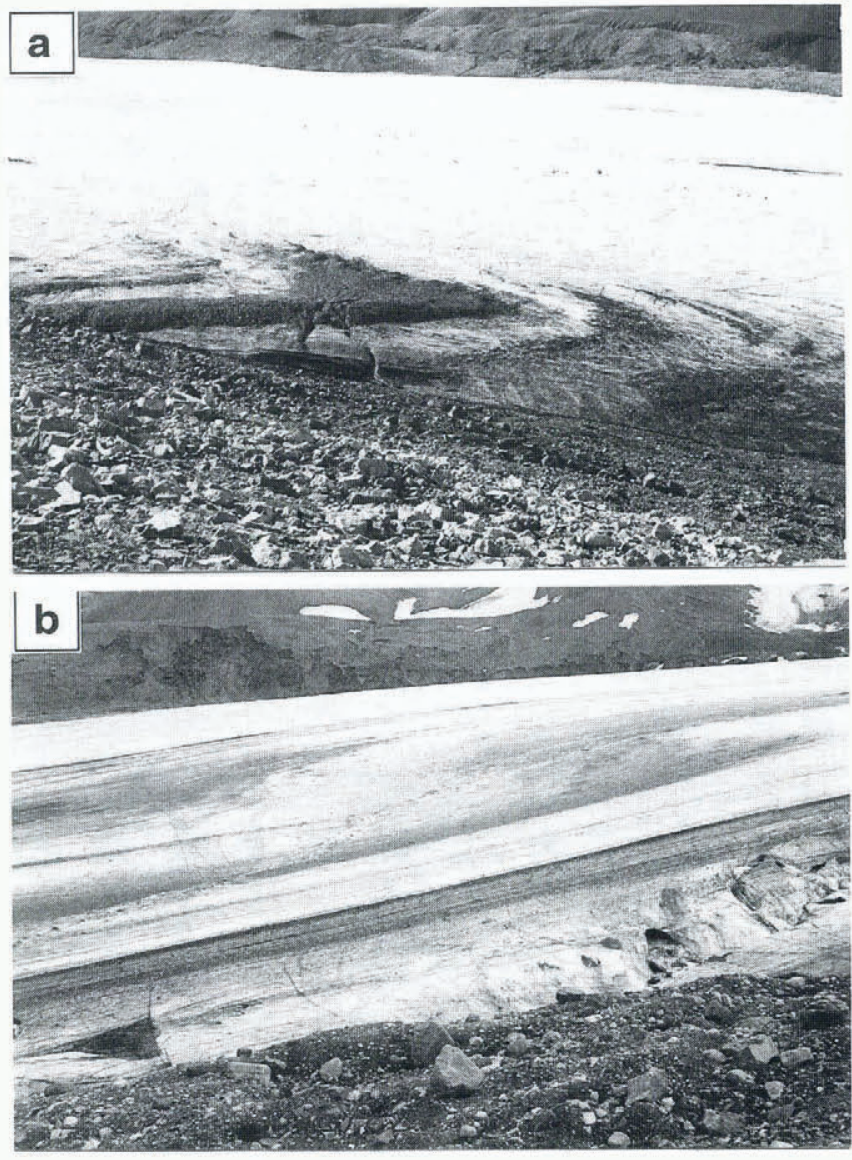

Fig. 8. Modification of stratification-parallel debris layers in surge-type glaciers. (a) Moraine loops at the east margin of Hessbreen; ice flow is to the right; the debris layers represent the surface expression of folds with axes gently dipping upglacier to the left. (b) Moraine loops of a more diffuse nature near the west margin of Finsterwalderbreen; these assymetrical fold structures have steep limbs where the ice/debris boundary is clearly defined, and gently dipping limbs where diffuse; the fold axes form a very low angle with the ice surface, with a relative dip up-glacier to the right.

faces, especially limestones and mudstones. The sediment is poorly sorted, with a large proportion $(30 \%$ or more) of mud, in addition to sand and gravel. Boulders are smaller than those concentrated in stratification, rarely exceeding $1 \mathrm{~m}$ in diameter.

Although most foliation-related debris of basal derivation is concentrated in marginal foliation, a number of examples of medial moraines containing such material have also been noted. A small ridge near the snout of Kongsvegen (Fig. 10b) runs parallel to foliation for at least $100 \mathrm{~m}$, emerging from clean ice as a debris-bearing fold, with steep limbs and a fold axis gently plunging up-glacier. This ice is coarsegrained and clear, and had the appearance of regelation ice, for example the "stratified facies" of Knight (1997; fig. 8). Furthermore, the two-dimensional clast fabric shows a preferred orientation parallel to the foliation, although this is not as strong as for debris associated with folded stratification (Fig. 6c). A much larger ridge of basally derived debris, running parallel to foliation in the middle of a large medial moraine, is evident further up-glacier; this must have been uplifted at least $100 \mathrm{~m}$ from the bed. Near the snout of Hessbreen, a prominent septum of basal debris with a number of point sources is evident in the core of folds containing supraglacial debris.
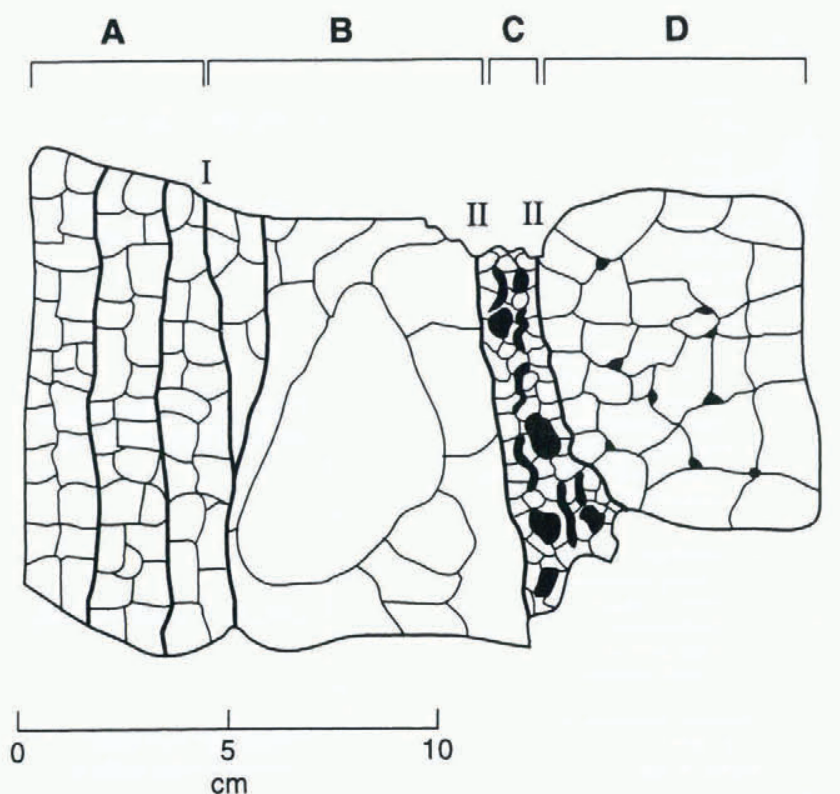

\section{Description of ice facies:}

A Coarse bubbly ice with crystals typically $2 \mathrm{~cm}$ diameter; bubbles in trains, mainly spherical to slightly elongate up to $2 \mathrm{~mm}$ diameter; little debris.

\section{B Coarse clear ice with crystals up to $5 \mathrm{~cm}$ diameter}

C Debris-rich ice with mud to pebble-sized material, with larger clasts elsewhere; subrounded and subangular shapes dominant

D Coarse clear ice with crystals typically $1-2 \mathrm{~cm}$ in diameter; numerous mud clots at inter-crystal boundaries

\section{Description of ice facies boundaries:}

I Planar discontinuity defined by $2 \mathrm{~mm}$ wide zone of bubbles; crystal boundaries do not cross the discontinuity; branching plane has clots of mud

II Boundary defined by the serrated edges of angular ice crystals; mud-clots up to $2 \mathrm{~mm}$ diameter at coarse clear ice boundaries

Fig. 9. Crystal structure associated with debris-rich foliated ice of longitudinal orientation at the surface of Bakaninbreen, just below surge front in 1994. The debris is apparently of basal origin.

\section{Debris associated with arcuate transverse layers (thrusts)}

\section{Origin of arcuate debris layers}

Fracturing in glacier ice is a common phenomenon, so that by the time the ice reaches the snout, numerous intersecting sets of crevasse traces are visible, presumably reflecting several generations of crevasse formation. Where glaciers have steep sides, some fracture-sets taper up from the basal ice layer in a convex down-glacier arc. These sets intersect the surface at a variety of angles: typically $20-40^{\circ}$ for nonsurge-type glaciers and up to $60-70^{\circ}$ for surge-type glaciers (Hambrey and others, 1996). These same fractures may form gently curving arcs at the glacier surface, and some are associated with debris.

Such fractures have a variety of origins. Firstly, they could simply be rotated transverse crevasse traces (cf. Hambrey and Müller, 1978), the debris having washed or fallen into open crevasses. Secondly, they may be basal crevasses into which debris has been squeezed (Sharp, 1985) and then deformed by differential flow. Thirdly, they could be thrusts, as described by Hambrey and others (1996) and Murray and others (1997). 


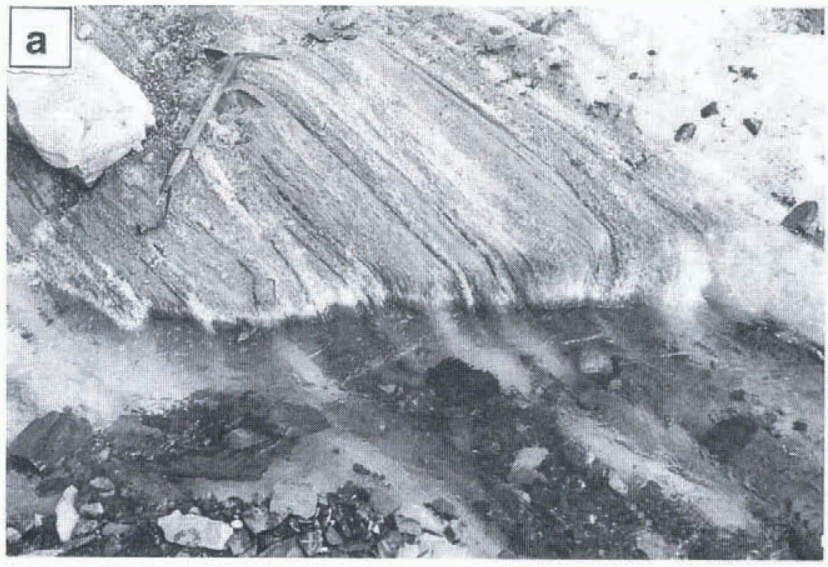

b
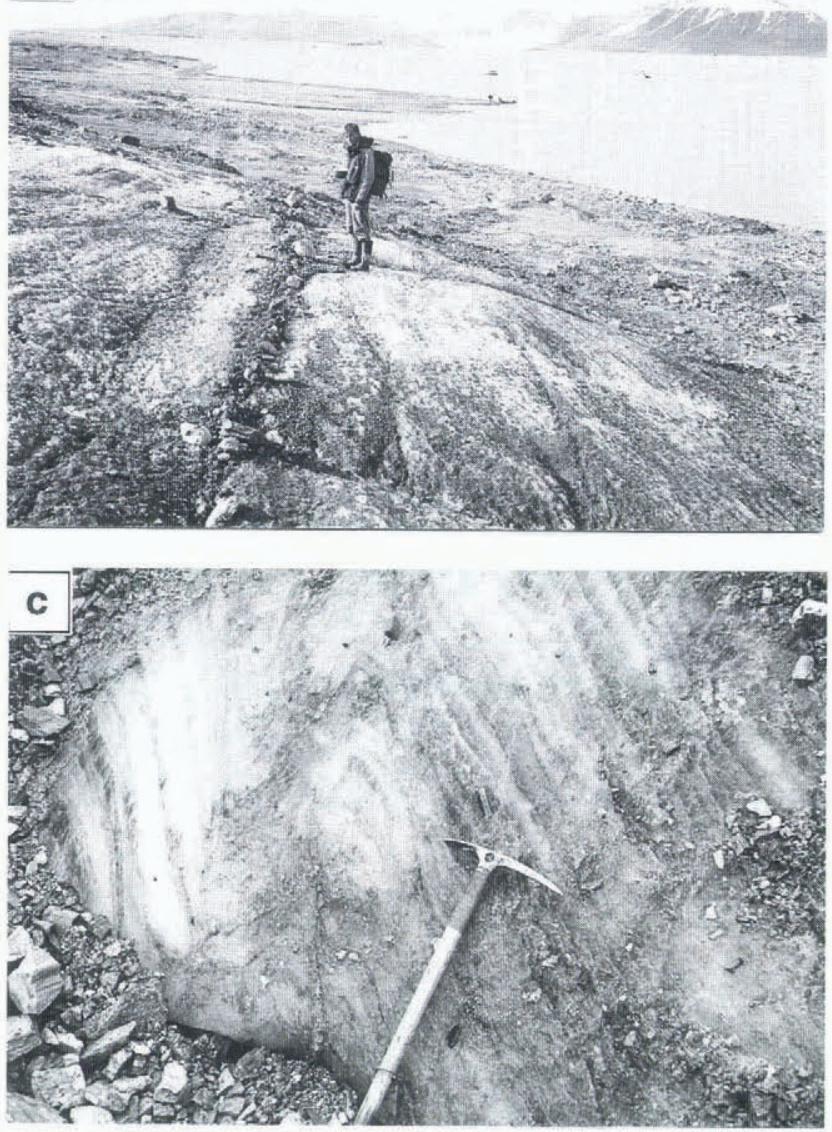

Fig. 10. Debris incorporated in longitudinal foliation. (a) Ice-marginal foliation, Hessbreen, comprising disseminated debris inferred to be of basal origin. (b) Septum of mud, sand and gravel, incorporating striated boulders, inferred to be derived from basal till, snout of Kongsvegen. (c) Folding of the "similar-type" folding and associated foliation, with sandy gravel of presumed basal origin, Pedersenbreen.

Criteria for the recognition of thrusting

Thrusts may be recognised on the basis of the following criteria:

(i) evidence of discrete truncation of older structures (e.g. crevasse traces or stratification), with the up-glacier ice riding over down-glacier ice; this provides the best indication of thrusting;

(ii) zones of mylonitised ice (fine ice with microshears), associated with the fractures; these may be evident in recently active ice (e.g. in Bakaninbreen which surged recently; Hambrey and others, 1996); (iii) clean fractures with narrow zones of debris-rich basal ice, or even slabs of frozen subglacially derived sediment, above;

(iv) sharply defined zones of coarse clear ice (a few $\mathrm{cm}$ to $0.5 \mathrm{~m}$ wide), which represent recrystallisation after thrust formation;

(v) direct measurements of displacements in active ice; the opportunities for these, however, are remote, as most fractures may no longer be active.

It is rare for all of these criteria to be fulfilled. However, if only one or two structures show these characteristics, and numerous other structures display a similar form and geometry, the implication is that they all have a common genesis. It is rare that one can "prove" that thrusting has taken place in Svalbard glaciers, but the authors believe that the weight of evidence indicates that this is an important process, and that most of the arcuate debris layers are indeed thrusts.

\section{Relationship between ice types and debris in thrusts}

In detail, the thrusts or thrust zones recognised in the Svalbard glaciers studied are often structurally complex. At their simplest, they are represented by a clean fracture, sometimes with a thin smear of mud. Most common are zones of coarse clear ice several $\mathrm{cm}$ wide with sharply defined boundaries and a suture in the middle. This ice probably became recrystallised following cessation of movement. Next are zones of clear, strongly foliated ice several $\mathrm{cm}$ wide, with irregularly disseminated debris of mud to gravel size, which resembles regelation ice derived from the bed. Most striking are zones up to $0.5 \mathrm{~m}$ wide, composed of many sediment types, which have only limited interstitial ice. Zones of mylonitised ice are rare since active thrusting today is probably uncommon, except in glaciers that have recently undergone a surge, and such ice rapidly recrystallises.

Normally, on the surface of the glacier, debris is exposed in a narrow zone extending for several metres, but the fracture bearing the sediment may extend for $100 \mathrm{~m}$ or more (Fig. 1la). In vertical sections, where the entire depth of a thrust zone may be observed, as at Hessbreen, the sole thrust may be at the contact between the bed and the basal ice, but one or two additional bed-parallel displacements may also be identifiable in the regelation ice layer. Such displacement zones are very rich in debris, and it is from the uppermost of these that the main set of thrusts rises (Fig. $11 \mathrm{~b}$ and $\mathrm{c}$ ). By this means, typical basal ice facies (Hubbard and Sharp, 1995; Hubbard and others 1996) may be uplifted to elevated positions within the ice mass (Fig. 1le and f), and may even be overturned. Once the debris reaches the surface, ablation concentrates the debris, which in turn retards ablation locally. Thus, prominent ridges form, the upglacier face commonly preserving the angle and rectilinear form of the thrust (Fig. 1ld).

The distribution of debris in thrusts is highly irregular. Examples observed at Kongsvegen show thick sediment wedges at the base, thinning out gradually or ending abruptly several metres above the base. Some thrusts have subsidiary thrusts; others bifurcate, both with and without debris. Some thrusts terminate abruptly before reaching the surface, and hence are termed "blind" (Murray and others, 1997). The lack of obvious thrusts at the surface of many glaciers, except in the lowermost kilometre or so, may be because the thickness of the ice has a strong bearing 
a

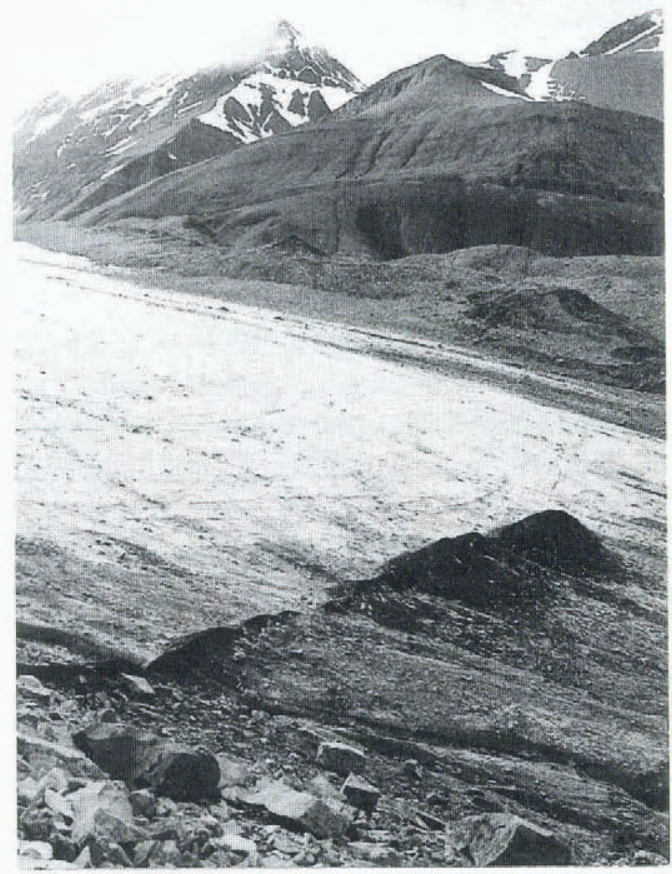

\section{b}

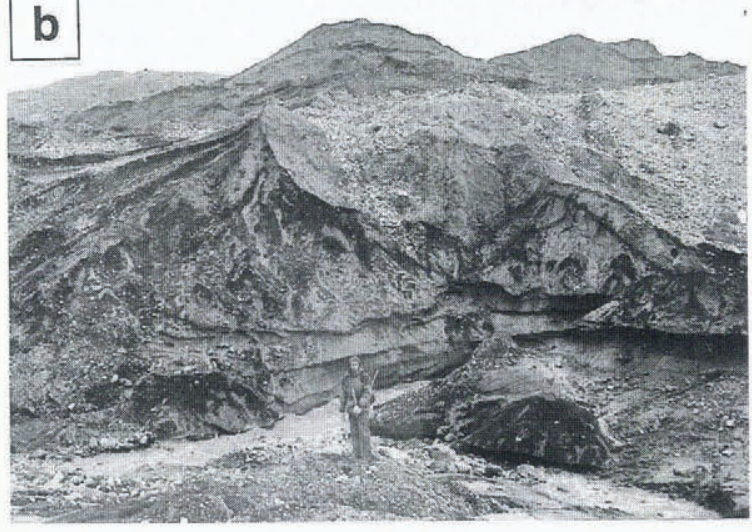

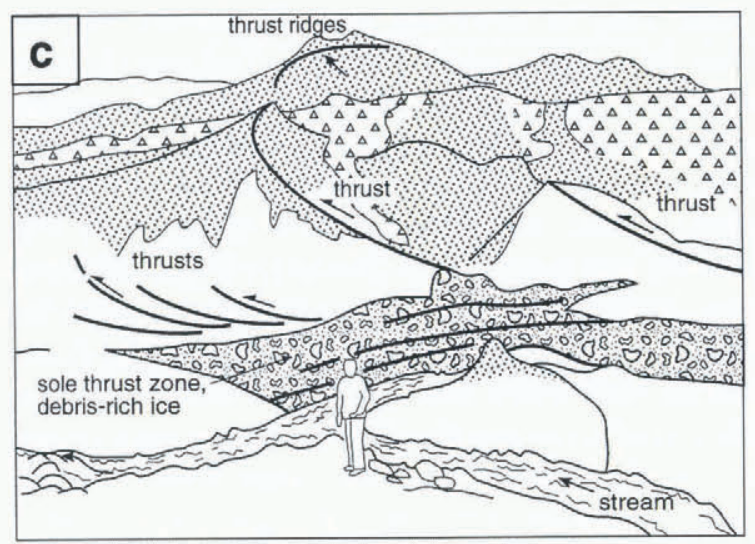

98. debris-rich $\quad 3$ debris derived $\Delta_{\Delta \Delta \Delta}^{\Delta}$ debris d

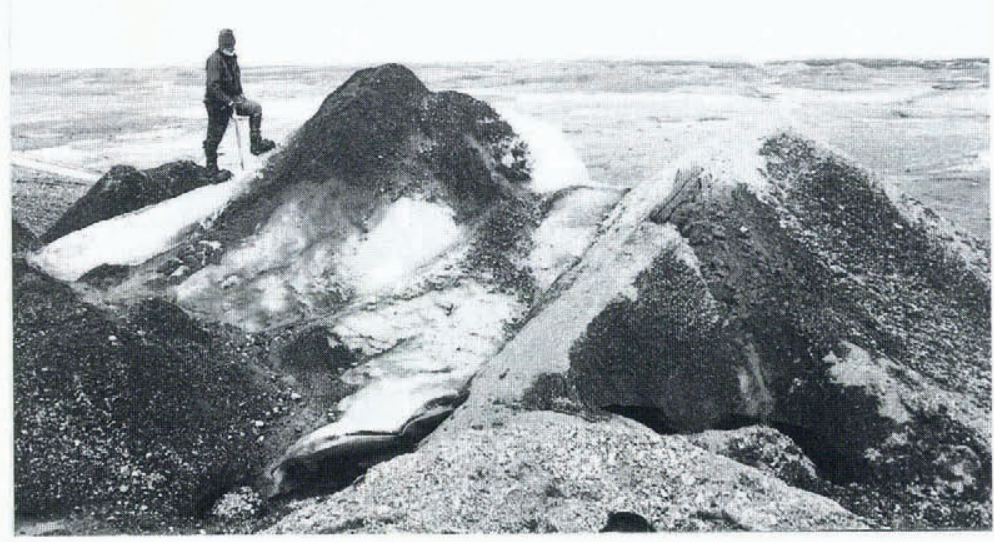

e

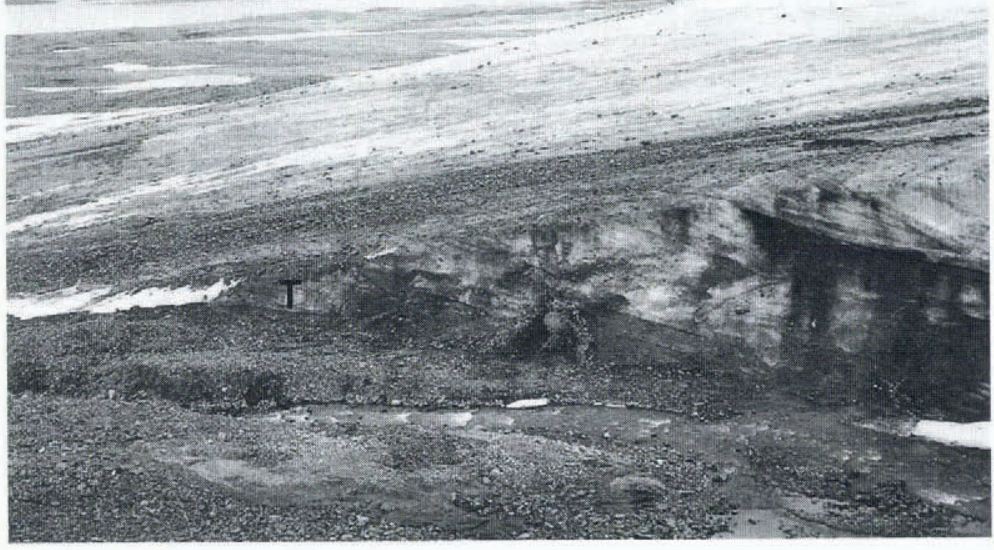

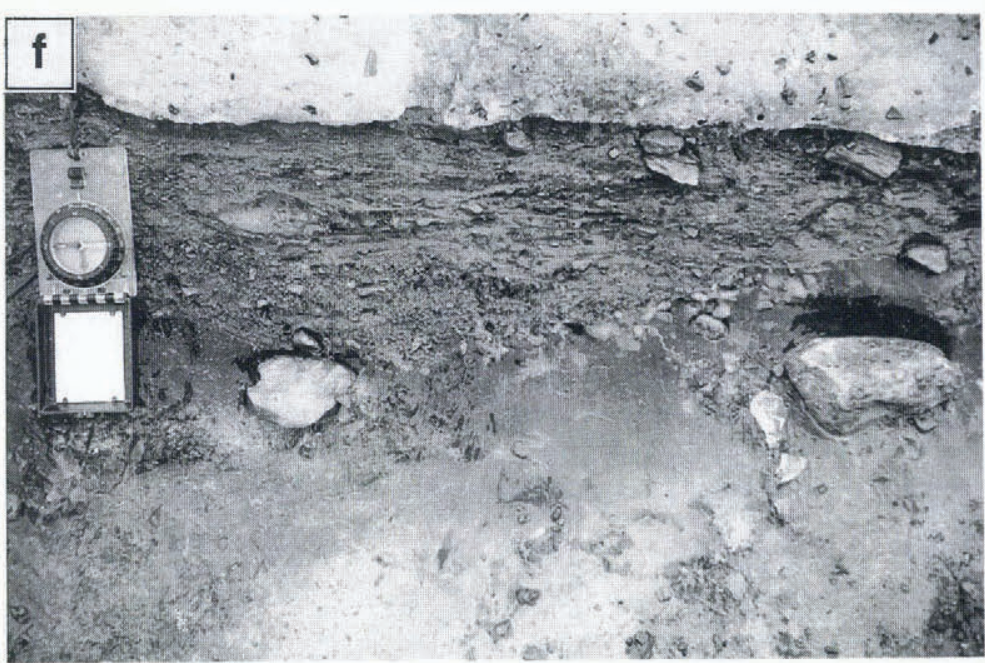

Fig. 11. Incorporation of subglacial debris by thrusting. (a) View of lower part of surge-type Hessbreen in its quiescent state showing transverse ridge of sandy gravel, as well as debris-free thrusts. (b, c) Dead ice at snout of Hessbreen, illustrating lowangle décollement surfaces from which moderately high-angle thrusts have propagated. These were probably formed in active ice during a surge. Ice rich in basal debris is dark-coloured, some of which penetrates the light-coloured supraglacial debris at the surface. Relatively clean ice, though smeared with debris on the surface, is indicated by white areas above stream in (c). (d) Thrusts bearing a low concentration of sandy gravel forming mounds at the surface of Midre Lovénbreen, as a result of differential ablation. (e) East margin of Midre Lovénbreen illustrating low-angle thrusts. $(f)$ Close-up view of thrust zone marked $T$ in Figure 7e, showing basal debris-rich regelation ice below the sharp displacement at the top of the photograph. 
on whether thrusts remain blind. Although some thrusts may be reactivated from older crevasse traces, as on White Glacier, Axel Heiberg Island (Hambrey and Müller, 1978), most appear to be later, cross-cutting structures. However, subsidiary thrusts sometimes appear to take advantage of existing layering (e.g. stratification).

Although it is likely from the above evidence that thrusting is the dominant means whereby debris is lifted to a high englacial or supraglacial position, this process is not the only indication of deformation processes at the bed. Even before thrusting takes place, layers (such as regelation layering and stratification) are subjected to recumbent folding which, if taken to its ultimate limit, results in the shearing off of the lower limb of the fold and the initiation of a thrust (Fig. 12). The folding process itself thus provides a mechanism for uplifting debris, as has been described previously, but without thrusting, by Hudleston (1976).

\section{Sedimentology of thrust debris}

Sedimentary facies associated with thrusting are much more variable than those derived from supraglacial sources. Diamicton has been noted on the surface of several glaciers (Fig. 13a), notably Bakaninbreen and Kongsvegen, both surge-type glaciers. The diamicton is massive or weakly stratified, and contains material from clay to boulder size of varied lithology, and the gravel clasts are commonly striated and faceted. Clast shapes range from very angular to rounded, with a predominance of mean values in the subangular and subrounded categories (Fig. 7). The discrimination with supraglacially derived debris is demonstrated by means of an RA/C 40 plot (Fig. 7b). All these attributes indicate that this facies is derived from basal glacial debris or subglacial till. Diamicton does not form clearly defined ridges, because on contact with melting ice it flows readily, thus smearing the ice surface, commonly for some tens of metres.

Also common are sandy gravels and gravelly sands, in which the grain-size distribution is much narrower than for diamicton. Pebble- and cobble-sized material is normal, and in cleaned sections appears to be relatively structureless (Fig. 13b). Gravelly sand facies, however, sometimes preserve plane-bedding and cross-bedding, inherited from the source material and little modified despite being uplifted to the surface. Clast shapes resemble those in diamicton, confirming the findings in the proglacial area that glaciofluvial sediments and diamictons have similar clast-shape distributions (Fig. 7; cf. Bennett and others, 1997).

Mud, sometimes with sand, commonly forms thin films on otherwise debris-free, thrust surfaces, but it is likely that at depth, diamicton is present and provides the source for the mud. On one glacier, Bakaninbreen, the bed is below sea level, and the mud is thus probably of glaciomarine origin.

The fabric of clasts associated with thrusts has been measured at several localities (Fig. 14). Compared with basal ice, which has a strong fabric parallel to flow (Fig. 14a), thrusts have weak girdle (Fig. 14b), or multi-maxima (Fig. 14c and d) fabrics. However, in the case of one lowangle thrust uplifting basal ice, the original fabric parallel to south-north flow is preserved, although it is weakened by the development of a transverse fabric (Fig. 14e). At none of the sites do the clast fabrics associated with the thrusts show any clear geometrical relationship with the thrusts. Perhaps the pre-thrusting fabrics are already variable, while the thrusting process itself can modify the fabric significantly or not at all.

\section{DISGUSSION}

\section{Debris entrainment and transport mechanisms}

Several modes of debris entrainment and subsequent deformation have been identified in polythermal glaciers in Svalbard: regelation and shearing in basal ice; folding of stratification; incorporation of basal debris in fold-generated foliation; deposition in foliation-parallel supraglacial and englacial streams followed by deformation; and thrusting. Of these, the regelation mechanism has not yet been studied in any detail in Svalbard glaciers. However, it is

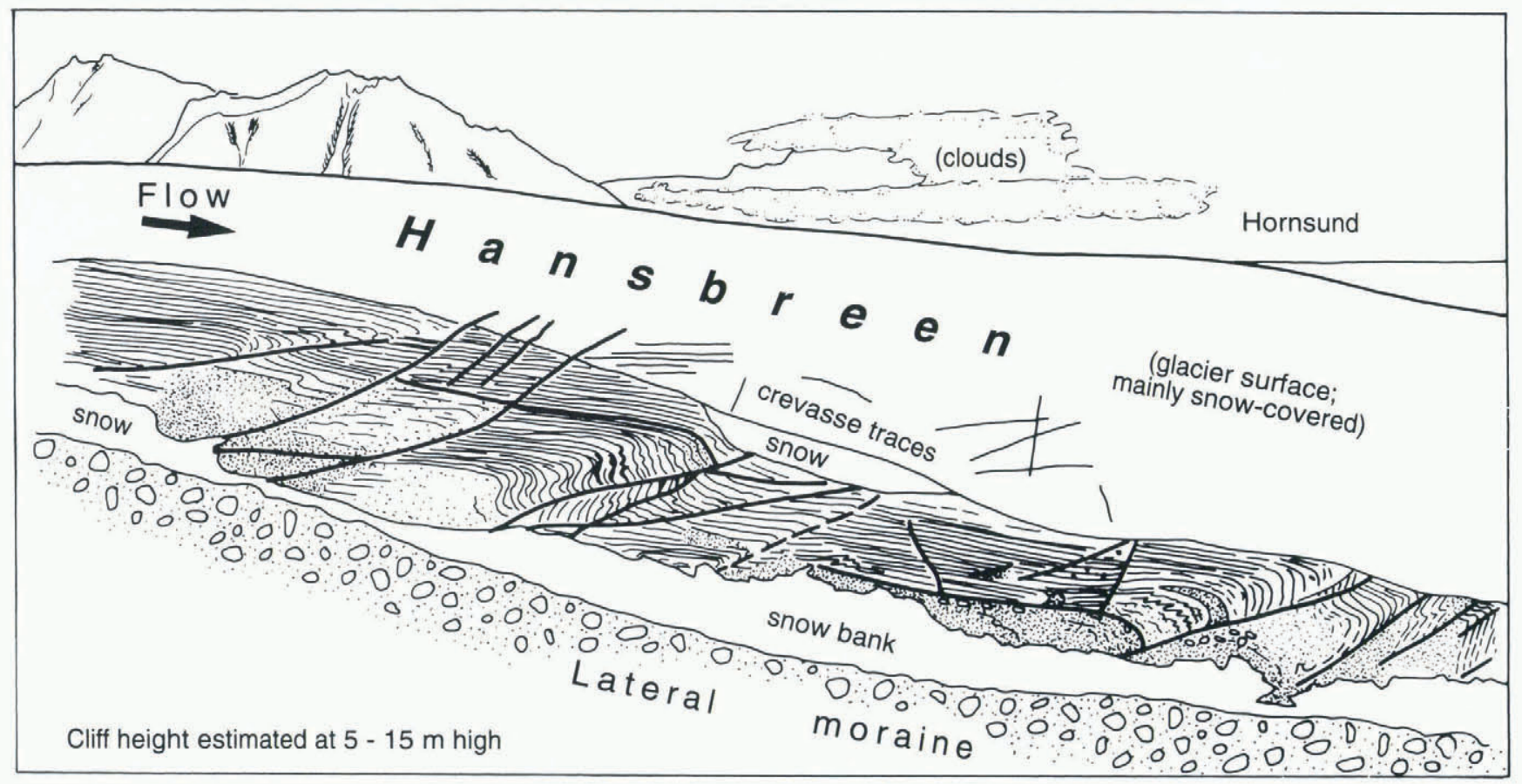

Fig. 12. Section along west margin of Hansbreen, illustrating the relationships between debris (stippled), thrusting with debris entrainment (thick lines) and recumbent folding (thin lines) (drawn from photographs). 

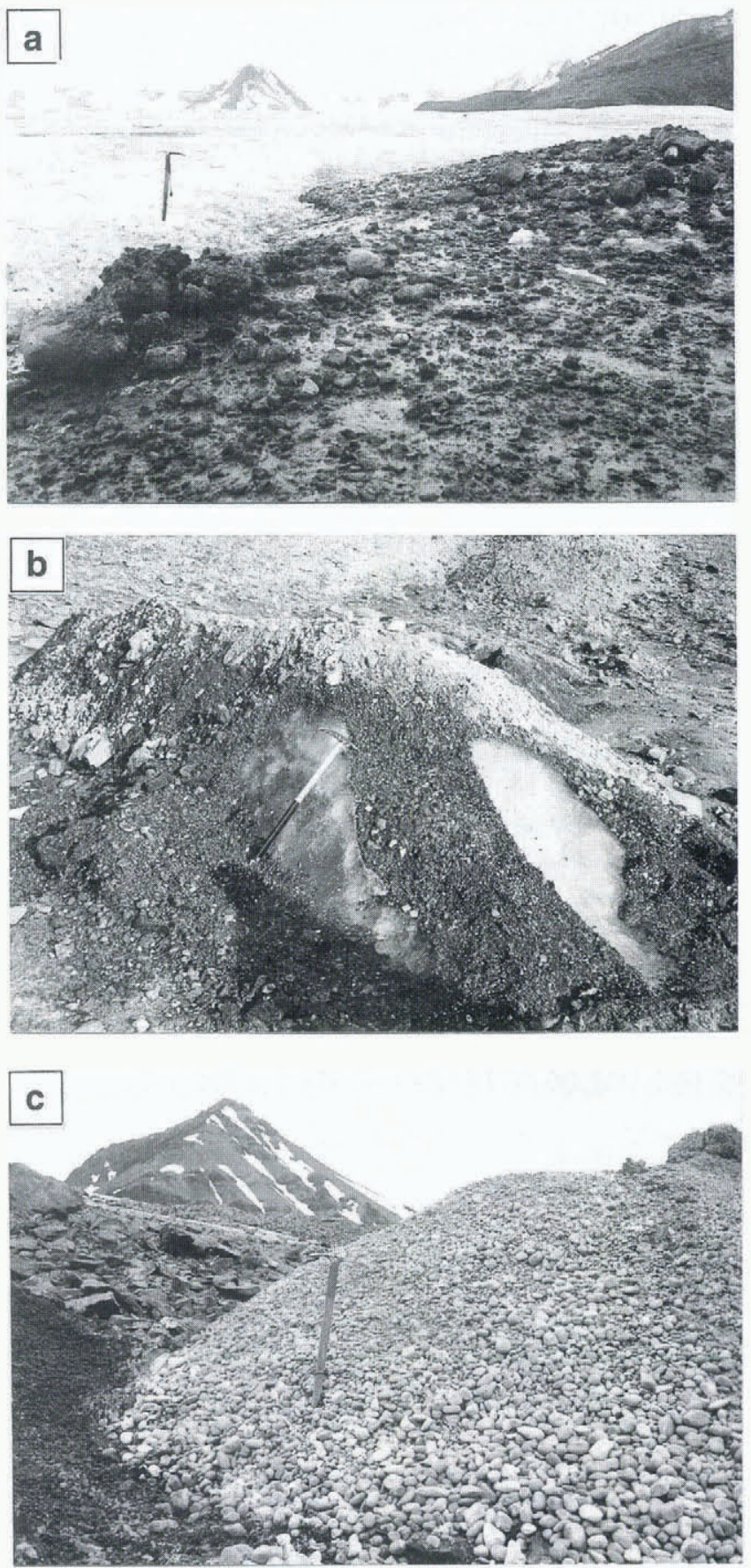

Fig. 13. Typical sedimentary facies associated with thrusting. (a) Diamicton emerging at a high-angle thrust which has brought debris-rich basal ice to surface; flowage of the released debris has smeared the glacier surface, close to the surge front of Bakaninbreen; this material is inferred to be typical basal debris or till. (b) Cleaned cross-section of a mass of thrust sandy gravel at the snout of Pedersenbreen; this material, interpreted as glaciofluvial sediment, contains only a minor amount of interstitial ice, and the mound is almost disconnected from the glacier. (c) Rounded gravels emerging from thrust at the snout of Midre Lovénbreen in contrast to the angular rockfall-derived supraglacial debris to the left; these gravels are provisionally interpreted as reworked raised beach deposits.

known from other glaciers in the Arctic that several metres of regelation ice may build up (e.g. Gemmell and others, 1986), while in alpine glaciers as many as seven different basal ice facies have been identified (Hubbard and Sharp, 1995; Hubbard and others, 1996).

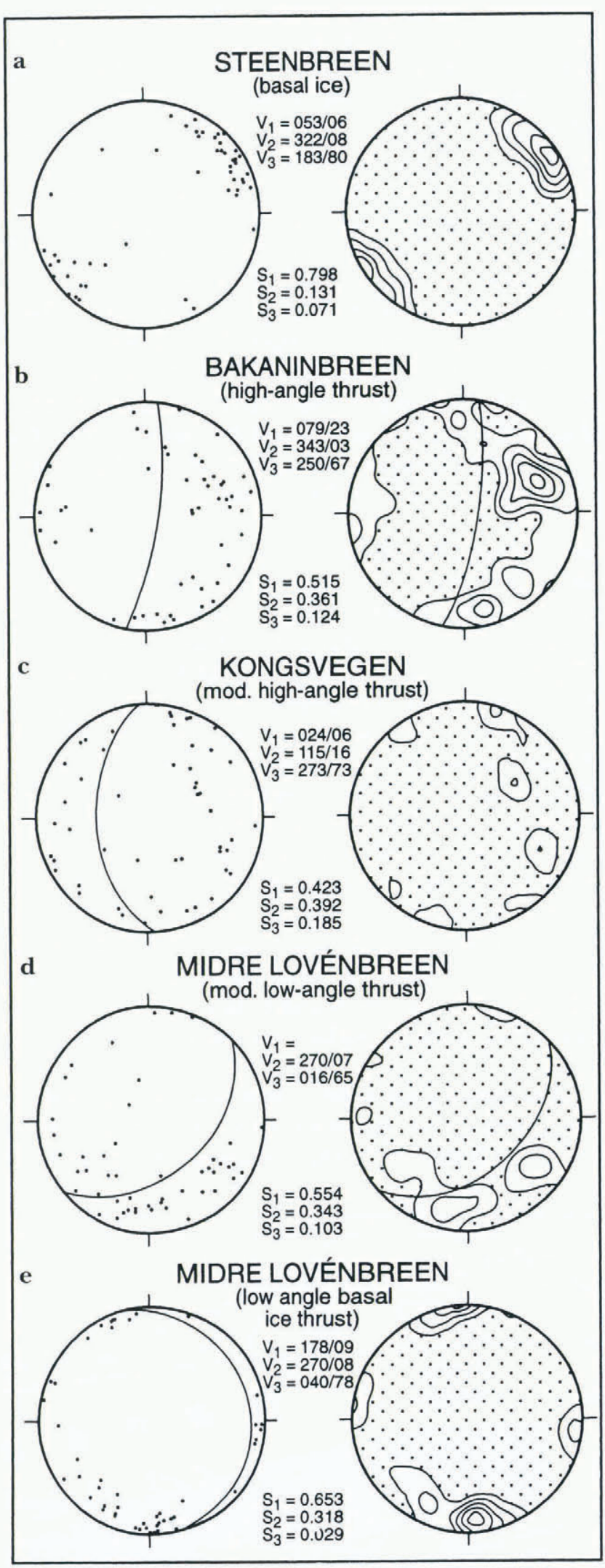

Fig. 14. Clast fabric data from thrusts in various glaciers; Schmidt lower-hemisphere equal-area projections including point plots, contour plots with contours at $2 \%$ intervals per $1 \%$ of area, and eigenvalues. Fifty clasts were measured at each site.

The supply of rockfall debris, its subsequent transport in a high-level position, and its role in the development of medial moraines on valley glaciers has received much attention, especially in Alpine regions (e.g. Boulton, 1978; Eyles and Rogerson, 1978; Boulton and Eyles, 1979; Small and 
others, 1979). However, the role played by large-scale folding within glaciers in the production of medial moraine systems does not appear to have been widely recognised. Largescale folding may be associated with glaciers of a particular morphology, that is those containing multiple accumulation basins, feeding into a narrow tongue with no icefall. Glaciers of this morphology represent the normal type of self-contained valley glacier in Svalbard today. In order to explain the relationships between the distribution and form of debris layers, and the primary folded stratification, a conceptual model (Fig. 15) has been developed. This shows in plan view and cross-section how debris which falls into the upper accumulation basins is transported along converging flowlines (profile $\mathrm{AA}^{\prime}$ ). This results in folding of the stratification, especially where transverse compression is strong at the narrowing of the glacier channel (profile $\mathrm{BB}^{\prime}$ ). This folding is not of uniform intensity, but is characterised by zones of tight and isoclinal folding. It is the emergence from an englacial position of tightly folded debris-bearing limbs, trending parallel to ice flow, that produces medial moraines (profile $\mathrm{CC}^{\prime}$ ).

In the cores of some tightly folded zones, in which a strong axial-planar longitudinal foliation is developed, debris of subglacial origin is present, especially in the lower $1 \mathrm{~km}$ or so of the glacier. Although some authors have argued that basal glacial debris can be incorporated into an englacial position under conditions of diverging ice flow which results in a type of helicoidal flow within the ice body (Shaw, 1975; Aario, 1977), these ideas are contrary to our understanding of basal ice mechanics (Menzies, 1995). Perhaps

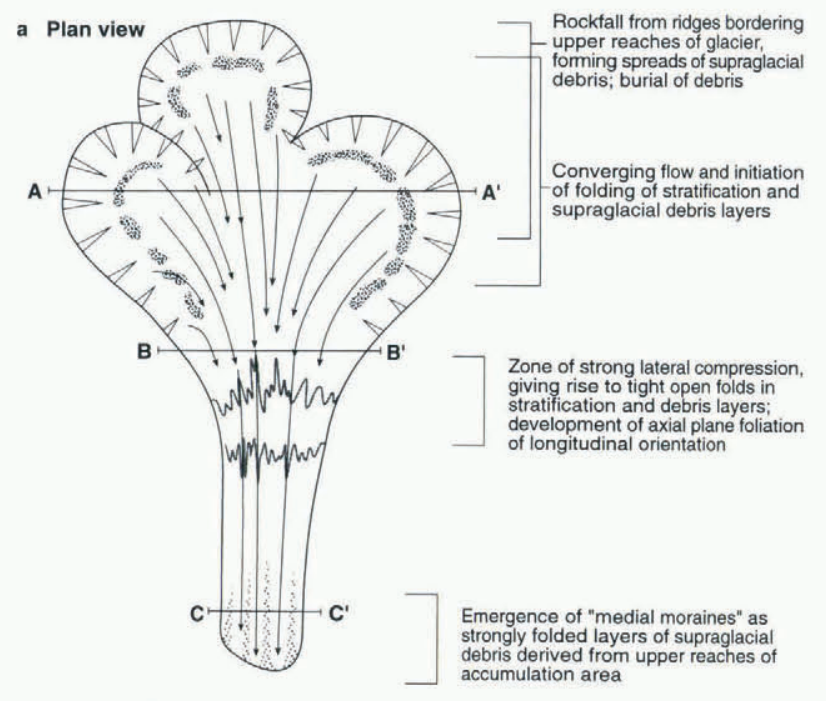

b Cross-sections

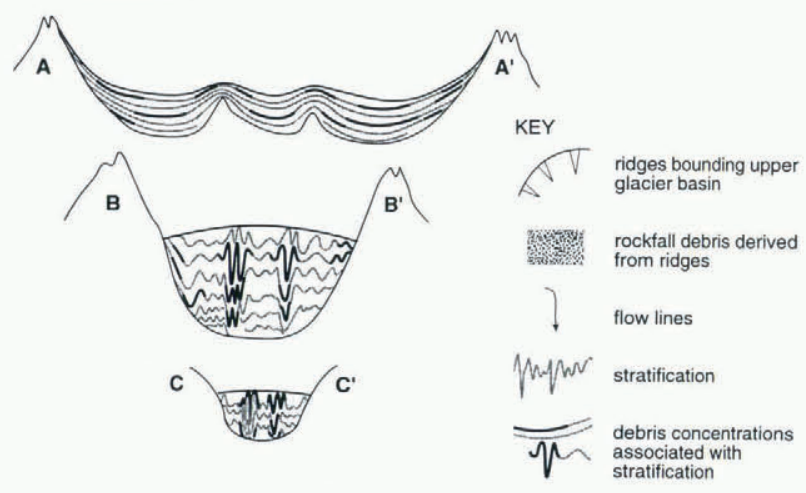

Fig. 15. Schematic diagram illustrating the progressive downglacier folding of stratification, including debris layers. more realistic is the model developed by Eyles and Rogerson (1977) for temperate Berendon Glacier, British Columbia, Canada, which involves injection of basal marginal debris in deep crevasses, and redistribution by shearing at the zone of convergence between two glaciers. However, in the Svalbard glaciers studied we have evidence for a different mechanism. This involves folding with axes parallel to flow deep within the glacier, in the same way that the material transported at a high level is also folded. In other words, the basal debris forms simply the lower part of the fold sequence, but where the folding is most intense, this basal debris can reach the surface (Fig. 16). This basal debris may be contained in regelation ice, or it may represent deformable till. In any case, to explain the fold geometry, which in relation to the bedrock must have a disharmonic relationship, deformable material at the bed needs to be envisaged to act, possibly in association with sliding on bedrock, as the plane of décollement, at the ice/ bedrock interface. In a typical polythermal glacier, the décollement is unlikely to occur near the snout as the ice is frozen to the bed. Instead, it is inferred that the structure formed in the main zone of convergence, before being transferred relatively passively through the narrow tongue. It is accepted that, although this model seems to best fit the structural and sedimentological evidence, it needs to be tested. This would best be achieved by means of detailed structural mapping, the application of ground-penetrating radar techniques, as demonstrated on Bakaninbreen (Murray and others, 1997), combined with borehole studies of the glacier interior and the bed.

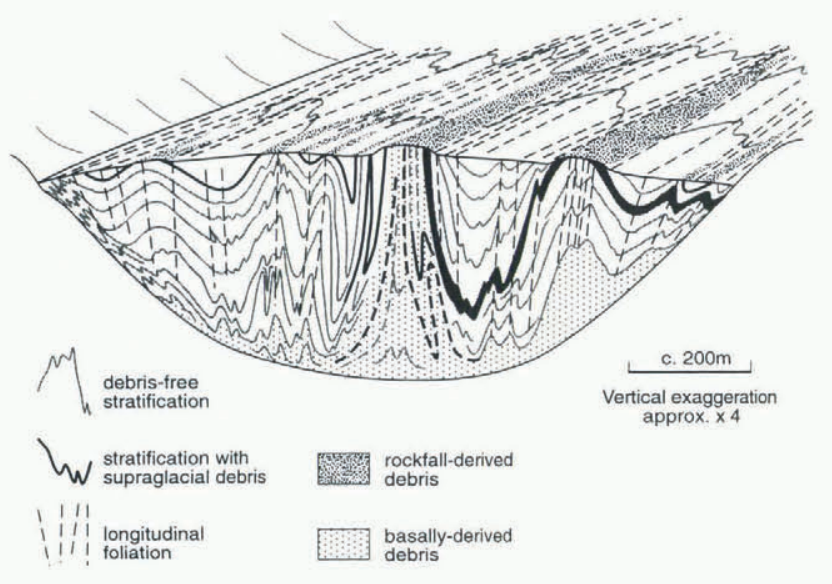

Fig. 16. Schematic cross-section of lower part of a Svalbard valley glacier, illustrating fold styles and subglacial debris septum.

The role of thrusting in the incorporation of debris has now been demonstrated using structural and sedimentological evidence in several Svalbard glaciers (e.g. Boulton, 1970; Bennett and others, 1996b; Hambrey and others, 1996; Hambrey and Dowdeswell, 1997; Murray and others, 1997; Glasser and others, 1998). Furthermore, the process has actually been observed to take place during a surge of a temperate glacier (Sharp and others, 1988).

Characteristically, except for isolated examples, thrusts mainly begin to appear at the ice surface within $1 \mathrm{~km}$ of the snout (Fig. 17). However, observations along steep glacier flanks suggest that the reason so few reach the surface higher up is because they are "blind" in ice more than several tens of 


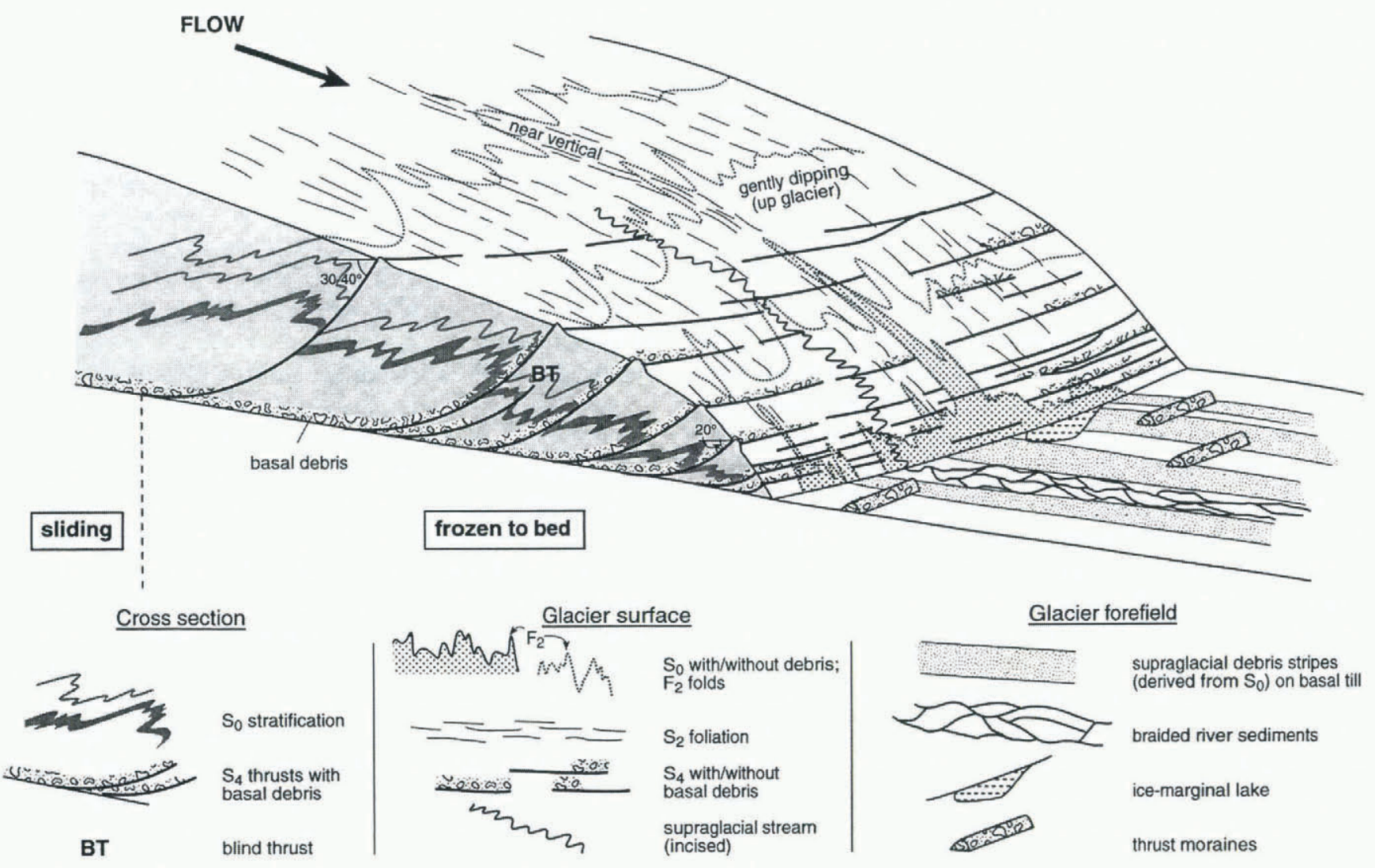

Fig. 17. Schematic three-dimensional view of the snout of a typical receding Svalbard valley glacier, showing relationships between folded stratification, longitudinal foliation, thrusting and debris distribution.

metres thick, i.e. the thrusts only propagate through the lower part of the ice mass. Most thrusts are not associated with significant volumes of debris, and most of those that do have debris ridges extending laterally for only several metres (Fig. 17). Exceptionally, however, individual debris ridges extending for $2 \mathrm{~km}$ have been noted, as on Uvêrsbreen (Hambrey and Huddart, 1995). These observations suggest that debris incorporation is non-uniform. Possibly, meltwater locally facilitates enhanced displacements along thrusts, enabling debris to be uplifted preferentially in such positions. Certainly, on rare occasions, evidence for subglacial water discharge along short lengths of thrusts has been documented, as on Bakaninbreen (Hambrey and others, 1996). Alternatively, concentrations of debris may occur where two thrusts intersect, as discussed by Bennett and others (in press).

In order for thrusts to develop, sliding displacements are necessary within the ice. Water is an ideal medium for lubricating thrusts; hence, their initiation is most likely to occur in temperate ice. In many cases, thrusts appear to be initiated in regelation ice, and a sole thrust may develop parallel to the regelation layering, but then rise upwards in a convex down-glacier arc (Fig. 11b). As suggested by Clarke and Blake (1991) and Hambrey and Huddart (1995), thrust initiation may take place preferentially where sliding ice meets ice that is frozen to the bed. Similarly, propagation upwards probably normally requires temperate ice, so if the upper part of the ice mass is cold, the thrust may terminate before breaking the surface, and would therefore be blind. Thrusts may also propagate upwards from bedrock irregularities, especially where ice is flowing over a rock step. Here, a décollement surface extends from the top of the step, which allows the upstream ice to flow much faster than ice in the lee of the step. This mechanism is evident in cliffs at the margin of Hessbreen, where the basal zone could be observed.

In many Svalbard glaciers today, thrusts occur in ice which is probably cold. Therefore it is unlikely that they formed where they are now visible. Either they formed much higher up-glacier, where temperate ice is present at the bed, or formed when the thermal regime was different, such as during the Neoglacial maximum when the glaciers were much thicker. Evidence that the ice is structurally inactive in at least one of the glaciers studied (Midre Lovénbreen) comes from the coarsely crystalline nature of ice adjacent to a thrust with strong preferred optic axis orientation bearing no relation to the orientation of the thrust (Fig. 18). This ice probably gained its present fabric in the lowstress conditions that characterise the ice front today.

\section{Comparison of debris transfer mechanisms in surge-type and non-surge-type glaciers}

All of the debris-entrainment mechanisms, described above, apply to both surge-type and normal glaciers in Svalbard. Thrusting of basally derived debris towards the glacier surface is a feature of both types of glacier, although in normal glaciers the surface expression of this process is limited mainly to within a few hundred metres of the snout, whereas in surge-type glaciers, thrusting may be evident much further up-glacier. It is thus likely that the greater propensity for thrusting in surge-type glaciers is responsible for their assimilating a larger amount of basal debris than normal glaciers, although this is not reflected in the distribution of debris at the surface.

There are some subtle differences in the manner in 


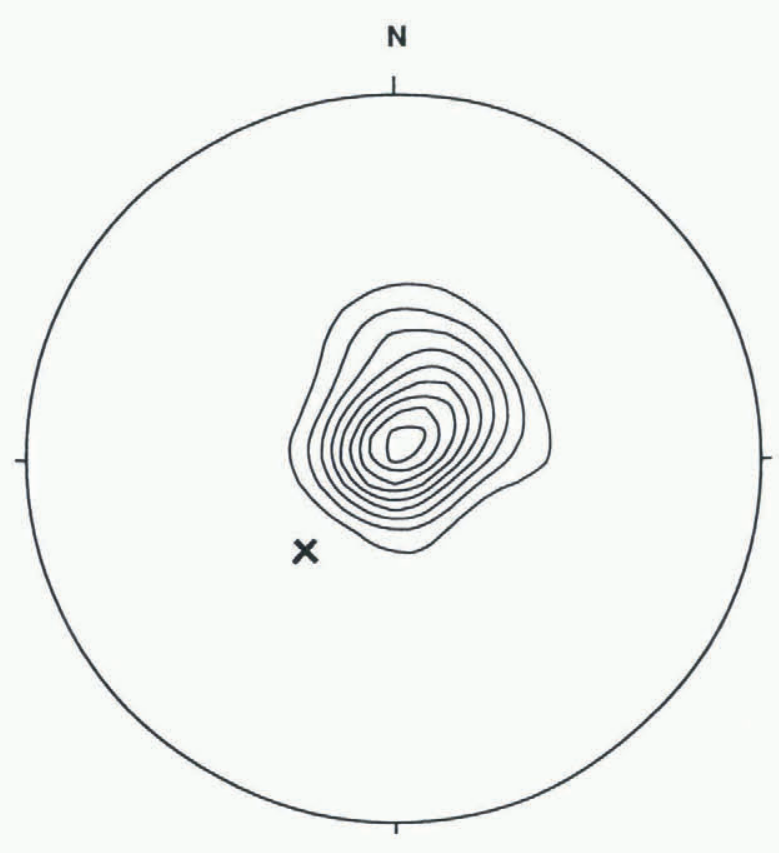

Fig. 18. Ice-crystal fabrics (c axes) near snout of Midre Lovénbreen (northeast side), plotted on Schmidt equal-area projection (lower hemisphere); contours at $4 \%$ intervals per $1 \%$ of area; number of crystals $=50$. c axes were obtained by measuring the basal plane of large crystals $(>1 \mathrm{~cm})$, defined by flattened bubbles in weathered ice. Pole to thrust plane indicated by cross.

which supraglacially derived debris is transported. In surgetype glaciers, the folding is relatively gentle and may lack an axial plane foliation. Surface moraines are commonly in the form of loops, reflecting folding of supraglacially derived debris layers, accompanied by rotation of fold axes. In normal glaciers, folding also occurs, but may be tighter, and the resulting supraglacial moraines are linear. These characteristics may be transmitted to the proglacial area during deposition; for example, a former moraine loop of surge-type Pedersenbreen can be mapped out as a curving train of angular debris in the proglacial area.

Basally derived debris associated with longitudinal foliation seems equally prevalent in both types of glacier. It generally is best developed near the margins, but occasionally forms longitudinal septa in mid-glacier; however, these features were only observed in two surge-type glaciers (Hessbreen and Kongsvegen).

\section{CONCLUSIONS}

Analysis of the distribution and character of debris transported in several polythermal valley glaciers in Svalbard demonstrates the importance of ice-tectonic processes that have been unrecognised or underestimated previously:

(1) The development of medial moraines is related to the incorporation of rockfall debris into the firn and ice within broad accumulation basins, followed by folding in response to lateral compression as the ice moves into a narrower tongue.

(2) It is suggested that the effect of the same phase of folding at the base of the ice mass results in the high-level incorporation of glacial debris of basal character from a bed of deforming till, to form longitudinal ridges at the glacier surface (Fig. 16).
(3) Incorporation of debris-rich basal ice and a variety of subglacial sedimentary facies by thrusting commonly results in large masses of debris which are transported towards the surface of the glacier, and deposited to form transverse ridges (Fig. 17). The initiation of thrusting is facilitated by (i) the transition from basal sliding to frozen-bed conditions near the terminus, (ii) the presence of bedrock steps, and (iii), in a surging glacier, the passage of the surge front through the system.

A number of implications arise from this work. Firstly, the distribution of fold-related ridges composed of rockfall debris has the potential, when combined with mapping of the source areas, of not only tracing particle paths through the glacier, but also defining the large-scale structure of the lower part of the glacier. Work of this nature would be enhanced substantially by the application of techniques to determine distribution of debris at depth in the glacier, such as ground-penetrating radar. Secondly, understanding the distribution of debris within the glacier system in the context of ice-structural evolution allows the development of improved models for the explanation of certain glacial depositional landforms, For example, flow-parallel linear ridges of angular debris are the proglacial continuations of medial moraines that were formed by strong folding of layers of rockfall-derived debris; while deposition from englacial debris-bearing thrusts leads to the development of at least one form of "hummocky moraine".

\section{ACKNOWLEDGEMENTS}

Financial support for this study was provided by Liverpool John Moores University, The University of Greenwich, the European Union Environment and Climate Programme (grant No. EN5V-CT93-0299) and the U.K. Natural Environment Research Council (grant No. GR9/02185). We thank N. Cox, Base Manager at the NERC Arctic Research Station and A.-M. Nuttall (University of Wales, Aberystwyth) for logistical organisation, and S. Ripper (Landscapes Graphics) for drafting most of the diagrams. The comments ofJ. C. Strasser and two anonymous referees have helped improve this paper.

\section{REFERENCES}

Aario, R. 1977. Classification and terminology of morainic landforms in Finland. Boreas, 6(2), 87-100.

Allen, C. R., W. B. Kamb, M. F. Meier and R. P. Sharp. 1960. Structure of the lower Blue Glacier, Washington. J. Geol., 68 (6), 601-625.

Alley, R. B., K. M. Cuffey, E. B. Evenson, J. C. Strasser, D. E. Lawson and G. J. Larson. 1997. How glaciers entrain and transport basal sediment: physical constraints. Quat. Sci. Rev., 16 (9), 1017-1038.

Benn, D. I. and C. K. Ballantyne. 1994. Reconstructing the transport history of glacigenic sediments: a new approach based on the co-variance of clast form indices. Sediment. Geol., 91 (1-4), 215-227.

Bennett, M. R. and N. F. Glasser, 1996. Glacial geolog): ice sheets and landforms. Chichester, etc., John Wiley \& Sons.

Bennett, M. R., M.J. Hambrey, D. Huddart and J. F. Ghienne. 1996a. The formation of a geometrical ridge network by the surge-type glacier. Kongsvegen, Svalbard. J. Quat. Sci., 11 6), 437-439.

Bennett, M. R., D. Huddart, M.J. Hambrey and J. F. Ghienne. 1996b. Moraine development at the high-Aretic valley glacier Pedersenbreen, Svalbard. Geogr. Ann., 78A 4), $209-222$.

Bennett, M. R., M. J. Hambrey and D. Huddart. 1997. Modification of clast shape in high-Arctic glacial environments. 7. Sediment. Petrol., 67, 550-559.

Bennett, M. R., M.J. Hambrey, D. Huddart, N. F. Glasser and K. Crawford. In press. The landform and sediment assemblage produced by a tidewater glacier surge in Kongsfjorden, Svalbard. Quat. Sci. Rev.

Björnsson, H. and 6 others. 1996. The thermal regime of sub-polar glaciers 
mapped by multi-frequency radio-echo sounding. F. Glaciol., 42 (140), 23-32.

Boulton, G. S. 1967. The development of a complex supraglacial moraine at the margin of Sorbreen, Ny Friesland, Vestspitsbergen. 7. Glaciol., 6 (47), $717-735$.

Boulton, G. S. 1970. On the origin and transport of englacial debris in Svalbard glaciers. .7. Glaciol., 9(56), 213-229.

Boulton, G. S. 1972. Modern Arctic glaciers as depositional models for former ice sheets. 7. Geol. Soc., London, 128 (4), 361-393.

Boulton, G. S. 1978. Boulder shapes and grain-size distributions as indicators of transport paths through a glacier and till genesis. Sedimentolog); $25(6), 773-799$.

Boulton, G. S. and N. Eyles. 1979. Sedimentation by valley glaciers: a model and genetic classification. In Schlüchter, C., ed. Moraines and varves: origin/genesis/classification. Rotterdam, A.A. Balkema, 11-23.

Clapperton, C. M. 1975. The debris content of surging glaciers in Svalbard and Iceland. f. Glaciol., 14 (72), 395-406.

Clarke, G. K. C. and E.W. Blake. 1991. Geometric and thermal evolution of a surge-type glacier in its quiescent state: Trapridge Glacier, Yukon Territory, Canada, 1969-89. J. Glaciol., 37(125), 158-169.

Clarke, T. S. 1991. Glacier dynamics in the Susitna River basin, Alaska, U.S.A. J. Glaciol., 37(125), 97-106.

Croot, D. G. 1988. Glaciotectonics and surging glaciers: a correlation based on Vestspitsbergen, Svalbard, Norway. In Croot, D. G., ed. Glaciotectonics: forms and processes. Rotterdam, A.A. Balkema, 4961.

Dowdeswell, J. A. 1986. The distribution and character of sediments in a tidewater glacier, southern Baffin Island, N.W.T., Canada. Arct. Alp. Res., $18(1), 45-56$.

Dowdeswell, J. A., G. S. Hamilton and J. O. Hagen. 1991. The duration of the active phase on surge-type glaciers: contrasts between Svalbard and other regions. J. Glaciol., 37 (127), 388-400.

Eyles, N. and R. J. Rogerson. 1977. Glacier movement, ice structures, and medial moraine form at a glacier confluence, Berendon Glacier, British Columbia. Can. 7. Earth Sci., 14 12), 2807-2816.

Eyles, N. and R. J. Rogerson. 1978. A framework for the investigation of medial moraine formation: Austerdalsbreen, Norway, and Berendon Glacier, British Columbia, Canada. f. Glaciol., 20(82), 99-113.

Gemmell, A. M. D., M. J. Sharp and D. E. Sugden. 1986. Debris from the basal ice of the Agassiz Ice Cap, Ellesmere Island, Arctic Canada. Earth Surf. Processes Landforms, 11 (2), 123-130.

Glasser, N. F., M. J. Hambrey, K. R. Crawford, M. R. Bennett and D. Huddart. 1998. The structural glaciology of Kongsvegen, Svalbard, and its role in landform genesis. F. Glaciol., 44 (146), 136-148.

Hagen, J. O. and A. Sætrang. 1991. Radio-echo soundings of sub-polar glaciers with low-frequency radar. Polar Res., 9 1), 99-107.

Hagen, J. O., O. Liestøl, E. Roland and T. Jorgensen. 1993. Glacier atlas of Svalbard and Jan Mayen. Nor. Polarinst. Medd. 129.

Hambrey, M. J. 1977. Foliation, minor folds and strain in glacier ice. Tectonophysics, 39 (1-3), 397-416.

Hambrey, M.J. 1994. Glacial environments. London, University College Press.

Hambrey, M. J. and J. A. Dowdeswell. 1997. Structural evolution of a surgetype polythermal glacier: Hessbreen, Svalbard. Ann. Glaciol., 24, 375-381.

Hambrey, M. J. and D. Huddart. 1995. Englacial and proglacial glaciotectonic processes at the snout of a thermally complex glacier in Svalbard. 7. Quat. Sci., 10 (4), 313-326.

Hambrey, M. J. and A. G. Milnes. 1977. Structural geology of an Alpine glacier (Griesgletscher, Valais, Switzerland). Eclogae Geol. Helv., 70 (3), 667-684.

Hambrey, M. J. and F. Müller. 1978. Structures and ice deformation in the White Glacier, Axel Heiberg Island, Northwest Territories, Canada. J. Glaciol., 20 (82), 41-66.

Hambrey, M.J., J. A. Dowdeswell, T. Murray and P. R. Porter. 1996. Thrusting and debris entrainment in a surging glacier: Bakaninbreen, Svalbard. Ann. Glaciol., 22, 241-248.

Hambrey, M. J., D. Huddart, M. R. Bennett and N. F. Glasser. 1997. Genesis of "hummocky moraines" by thrusting in glacier ice: evidence from Svalbard and Britain. 7. Geol. Soc., London, 153 (4), 623-632.

Hamilton, G. S. and J. A. Dowdeswell. 1996. Controls on glacier surging in Svalbard. 7. Glaciol., 42(140), 157-168.

Hart, J. K. 1995. An investigation of the deforming layer/debris-rich basalice continuum, illustrated from three Alaskan glaciers. 7. Glaciol., 41 (139), 619-633.
Hooke, R. LeB. 1973. Flow near the margin of the Barnes Ice Cap, and the development of ice-cored moraines. Geol. Soc. Am. Bull., 84 12), 39293948.

Hooke, R. LeB. and P. J. Hudleston. 1978. Origin of foliation in glaciers. J. Glaciol., 20 83), 285-299.

Hubbard, B. and M. Sharp. 1989. Basal ice formation and deformation: a review. Prog. Phys. Geogr., 13 (4), 529-558.

Hubbard, B. and M. Sharp. 1995. Basal ice facies and their formation in the western Alps. Arct. Alp. Res., 27 (4), 301-310.

Hubbard, B., M. Sharp and W.J. Lawson. 1996. On the sedimentological character of Alpine basal ice facies. Ann. Glaciol., 22, 187-193.

Huddart, D. and M. J. Hambrey. 1996. Sedimentary and tectonic development of a high-Arctic, thrust-moraine complex: Comfortlessbreen, Svalbard. Boreas, 25 (4), 227-243.

Hudleston, P. J. 1976. Recumbent folding in the base of the Barnes Ice Cap. Baffin Island, Northwest Territories, Canada. Geol. Soc. Am. Bull., 87 (12), 1684-1692.

Jania, J., D. Mochnacki and B. Gadek. 1996. The thermal structure of Hansbreen, a tidewater glacier in southern Spitsbergen, Svalbard. Polar Res., $15(1), 53-66$.

Kirkbride, M. and N. Spedding. 1996. The influence of englacial drainage on sediment-transport pathways and till texture of temperate valley glaciers. Ann. Glaciol., 22, 160-166.

Knight, P, G, 1997. The basal ice layer of glaciers and ice sheets. Quat. Sci. Rev., 16 9), 975-993.

Lawson, W. 1996. Structural evolution of Variegated Glacier, Alaska, U.S.A., since 1948. J. Glaciol., 42 (141), 261-270.

Liestøl, O. 1988. The glaciers in the Kongsfjorden area, Spitsbergen. Nor. Geogr. Tidsskr., 42 (4), 231-238.

Meier, M. F. and A. Post. 1969. What are glacier surges? Can. F. Earth Sci., 6 (4), Part 2, 807-817.

Menzies, J. 1995. Modern glacial environments: processes, dynamics and sediments. Vol. 1. Glacial Environments. Oxford, etc., Butterworth-Heinemann.

Murray, T., D. L. Gooch and G.W. Stuart. 1997. Structures within the surge front at Bakaninbreen, Svalbard, using ground-penetrating radar. Ann. Glaciol., 24.122-129.

Nuttall, A.-M., J. O. Hagen and J. Dowdeswell. 1997. Quiescent-phase changes in velocity and geometry of Finsterwalderbreen, a surge-type glacier in Svalbard. Ann. Glaciol., 24, 249254.

Odegård, R. S., S.-E. Hamran, P. H. Bø, B. Etzelmüller, G. Vatne and J. L. Sollid. 1992. Thermal regime of a valley glacier, Erikbreen, northern Spitsbergen. Polar Res., 11 (2), 69-79.

Post, A. S. and E. R. LaChapelle. 1971. Glacier ice. Seattle, WA, The Mountaincers and University of Washington Press.

Sharp, M. 1985. "Crevasse-fill" ridges - a landform type characteristic of surging glaciers? Geogr. Ann., 67A (3-4), 213-220.

Sharp, M., W. Lawson and R. S. Anderson. 1988. Tectonic processes in a surge-type glacier. f. Struct. Geol.. 10 (5), 499-515.

Sharp, M., J. Jouzel, B. Hubbard and W. Lawson. 1994. The character, structure and origin of the basal ice layer of a surge-type glacier. J. Glaciol., $40(135), 327-340$.

Shaw, J. 1975. The formation of glacial flutings. In Suggate, R. P. and M. M. Cresswell, eds. Quaternary studies: selected papers from 9th INQUA Congress, Christchurch, New Zealand, December 1973. Christchurch, Royal Society of New Zealand, 253 258. (Bulletin 13.

Shaw, J. 1980. Drumlins and large-scale flutings related to glacier folds. Arct. Alp. Res., $12(3), 287-298$.

Small, R. J., M. J. Clark and T. J. P. Cawse. 1979. The formation of medial moraines on Alpine glaciers. f. Glaciol., 22 (86), 43-52.

Sollid, J. L. and L. Sorbel. 1988. Influence of temperature conditions in formation of end moraines in Fennoscandia and Svalbard. Boreas, 17 (4), $553-558$.

Souchez, R. A. and R. D. Lorrain. 1991. Ice composition and glacier dynamics. New York, etc., Springer-Verlag.

Swinzow, G. K. 1962. Investigation of shear zones in the ice sheet margin, Thule area, Greenland. J. Glaciol., 4(32), 215-229.

Vere, D. M. and D. I. Benn. 1989. Structure and debris characteristics of medial moraines in Jotunheimen, Norway: implications for moraine classification. J. Glaciol., 35 (120), $276-280$.

Weertman, J. 1961. Mechanism for the formation of inner moraines found near the edge of cold ice caps and ice sheets. 7. Glaciol., 3 30), 965978. 